\title{
SYNTHESIS AND CHARACTERIZATION OF STARCH MALONATE: DEVELOPMENT OF FAST DISSOLVING TABLETS OF ACECLOFENAC BY $2^{3}$ FACTORIAL DESIGNS
}

\author{
ANNU KUMARI, R. SANTOSH KUMAR* \\ Gitam Institute of Pharmacy, Gitam (Deemed to be University), Rushikonda, Visakhapatnam, A. P. 530045, India \\ *Email: drsantoshrada@gmail.com \\ Received: 04 Sep 2020, Revised and Accepted: 08 Mar 2021
}

\begin{abstract}
Objective: The aim of the research work is to develop a new superdisintegrant (starch malonate) which can help in enhancing the solubility and drug dissolution of poorly soluble drugs. Hence, starch malonate (new superdisintegrant) was prepared and has been evaluated for its superdisintegrant property by incorporating it into fast dissolving tablets of Aceclofenac.

Methods: Superdisintegrant was developed by using esterification reaction. Prepared starch malonate was then subjected for different characterization tests (solubility, $\mathrm{pH}$, melting point, swelling index, FTIR, DSC studies. $2^{3}$ factorial design method was used to formulate fast dissolving tablets of aceclofenac employing starch malonate. Two known superdisintegrants croscarmellose sodium and crospovidone have been used along with starch malonate in combinations to develop fast dissolving tablets. Prepared tablets were then subjected to different tests for tablets like hardness, friability, disintegration time, dissolution studies. A stability study was performed to determine the stability of the formulation. Design expert study was conducted to know the interaction between different superdisintegrants and to select best optimized formulation in among all formulations.
\end{abstract}

Results: Starch malonate prepared was found to be fine, free flowing slightly crystalline powder, insoluble in aqueous and organic solvents. Tablets of all formulations were of excellent quality concerning drug content (100 $\pm 5 \%)$, hardness $\left(3.8-4.2 \mathrm{~kg} / \mathrm{cm}^{2}\right)$, and friability (less than $\left.0.15 \%\right)$. In all formulations, formulation F2 found to be optimized formulation with least disintegration time $38 \mathrm{~S}$, less wetting time $17 \pm 0.08 \mathrm{~s}$ and enhanced percent dissolved rate in 5 min i.e., $99.84 \%$ as compared to other formulations.

Conclusion: From this it was concluded that starch malonate can be used as a novel superdisintegrant to enhance the drug dissolution of poorly soluble drugs. Optimized formulation F2 showed enhanced drug dissolution at 5\% concentration as compared to other formulation and showed least disintegration time and enhanced drug dissolution as compared to other formulations and pure drug.

Keywords: Fast dissolving tablets, Superdisintegrant, Starch malonate, Aceclofenac, Dissolution efficiency

(c) 2021 The Authors. Published by Innovare Academic Sciences Pvt Ltd. This is an open access article under the CC BY license (https://creativecommons.org/licenses/by/4.0/)

DOI: https://dx.doi.org/10.22159/ijap.2021v13i3.40536. Journal homepage: https://innovareacademics.in/journals/index.php/ijap

\section{INTRODUCTION}

Solid oral dosage forms are the most stable and convenient dosage form of medicine as they are stable, easy to carry and affordable. Formulating a drug in a form which is more presentable and affordable is the first choice of physicians and patients.

Oral solid dosage forms have drug absorption of $50-60 \%$ of tota dosage forms. Solubility is the important parameter which affects the drug absorption of solid dosage forms. Solid dosage forms are widely accepted because of ease of administration, self-administration and low cost. Tablets are the most acceptable and stable dosage forms among solid oral dosage forms. These conventional solid dosage forms have showed difficulty in swallowing which is common challenge faced by old age people and children's [1]

Fast dissolving tablets are solid dosage forms which can disintegrate very fastly and can be suspended in mouth (saliva). These tablets have great advantage for bedridden, unconscious, psychotic, pediatric and geriatric patients [2]

Different methods are available for the preparation of fast dissolving tablets. Direct compression method by using superdisintegrant is the most economical and easy method. Superdisintegrants are used in fast dissolving tablets in order to disintegrate the tablets quickly. As per literature survey, both synthetic and natural superdisintegrant are already available in market.

In the present investigation study, the aim is to prepare a modified starch (starch malonate) and utilize it as superdisintegrant in the fast dissolving tablets. Starch is well known excipient used as disintegrant or binder based on its concentration. Starch has been modified by using physical and chemical reaction to modify its properties and to give modified starch with better disintegrant properties [4].
Different types of starch like potato starch, corn starch are biomaterials having wide pharmaceutical use and by subjecting it to different modification techniques. Corn starch has been used to prepare superdisintegrant using different silicates $[5,6]$.

In the present research, potato starch has been modified by esterification reaction. Fast dissolving tablets of aceclofenac were prepared by using $2^{3}$ factorial design employing starch malonate as superdisintegrant for enhanced dissolution of aceclofenac, a poorly soluble drug.

\section{MATERIALS AND METHODS}

\section{Materials}

Aceclofenac, croscarmellose sodium, crospovidone, starch and potato starch were purchased from Yarrow chemicals, Mumbai. Sodium hydroxide and mannitol were obtained from Finar chemicals Ltd, Ahmedabad. Malonic acid was purchased from Liha Life sciences Hyderabad. Microcrystalline cellulose was procured from Qualigens fine chemicals, Mumbai. Magnesium stearate and Talc was purchased from molychem, Mumbai.

\section{Methods}

\section{Preparation of starch malonate (New superdisintegrant)}

Starch malonate was prepared by using potato starch and malonic acid as starting material using esterification [7]. 10 parts of malonic acid and 10 parts of potato starch was dissolved in 25 parts of distilled water. The $\mathrm{pH}$ of the solution was checked and adjusted to 3.5 by adding $10 \mathrm{M} \mathrm{NaOH}$ solution to it. The resultant mixture was conditioned for $16 \mathrm{~h}$. After conditioning, the resultant product was kept in an oven at $60{ }^{\circ} \mathrm{C}$ until it gets dried. In order to remove the untreated malonic acid, the mass was washed with distilled water Again, the product was dried in oven at $60{ }^{\circ} \mathrm{C}$ until it gets dried. Product obtained was grounded and sieved through sieve no.120\#. 


\section{Characterization of starch malonate}

The starch malonate prepared was evaluated for the following

\section{Solubility}

Solubility of starch malonate was tested in distilled water, aqueous buffer of pH 1, 2, 3, 4, 5, 6, and 7.4 and organic solvents such as alcohol, dichloromethane, chloroform, acetone and petroleum ether [8]

pH

By $\mathrm{pH}$ meter, $\mathrm{pH}$ of $1 \% \mathrm{w} / \mathrm{v}$ slurry was checked [8].

\section{Melting point}

Melting point was checked by melting point apparatus [8].

\section{Viscosity}

The viscosity of $1 \%$ dispersion in distilled water was measured using Ostwald viscometer [8].

\section{Swelling index}

Starch malonate $(200 \mathrm{mg}$ ) was added to $10 \mathrm{ml}$ of water, and light liquid paraffin in two different measuring cylinders and mixed. The dispersion in the tubes was allowed to stand for $12 \mathrm{~h}$. The volumes of the sediment in the cylinders were recorded. The swelling index of the material was calculated as follows [8].

$S . I=\frac{\text { Volume of sediment in water }- \text { Volume of sediment in light liquid paraffin }}{\text { Volume of sediment in light liquid paraffin }} \times 100$

\section{Test for gelling property}

The gelling property of the starch and starch malonate evaluated by heating $7 \% \mathrm{w} / \mathrm{v}$ dispersion of each, in distilled water at $100{ }^{\circ} \mathrm{C}$ for $30 \min [8]$.

\section{Particle size}

By optical microscopy, particle size was determined.

\section{Density}

By using benzene as a liquid, the density $(\mathrm{g} / \mathrm{cc}$ ) measured by liquid displacement process [8].

\section{Bulk density}

For calculation of loose bulk density (LBD) and tapped bulk density (TBD) weighed number of samples were transferred to $50 \mathrm{ml}$ measuring cylinder and tapped for about 50 times on a plane surface. Tapped volume of packing was recorded. LBD and TBD measured by following formula [9].

$$
\begin{gathered}
\mathrm{LBD}=\frac{\text { Mass of powder }}{\text { Volume of packing }} \\
\mathrm{TBD}=\frac{\text { Mass of powder }}{\text { Tapped volume of packing }}
\end{gathered}
$$

\section{Percentage compressibility index}

Carr's compressibility index calculated to check the percent compressibility of powder mix. [9].

$$
\% \text { Carr's Index }=\frac{(\text { TBD }- \text { LBD })}{\text { TBD }} \times 100
$$

Where, TBD = Tapped bulk density; LBD = Loose bulk density

\section{Angle of repose}

The angle of repose measured through fixed funnel method [9]. Equation used to calculate the angle of repose is given below:

$$
\begin{aligned}
& \tan \theta=\frac{h}{r} \\
& \theta=\tan ^{-1} \frac{h}{r}
\end{aligned}
$$

Where $\theta=$ angle of repose; $h=$ height of pile; $r$ = radius of pile.

\section{Fourier transform infrared (FTIR) spectroscopy}

FTIR spectra of starch malonate recorded on samples prepared in potassium bromide $(\mathrm{KBr})$ disks using a BRUKER FT-IR, (Tokyo, Japan). $\mathrm{KBr}$ disks of samples were made at 6-8 tons hydrostatic press and analyzed sample between scanning range 500 to $4000 \mathrm{~cm}^{-1}$.

\section{Scanning electron microscopy (SEM)}

Surface morphology of the potato starch and starch malonate was confirmed by doing scanning electron microscopy. A double-sided sticking carbon tape of $200 \mathrm{~nm}$ thickness was used for placing the sample on SEM sample stub. Scanning electron photomicrographs were recorded at various magnifications to know the surface morphology of starch and starch malonate.

\section{Compatibility studies of selected drug with excipients}

For the formulation of any dosage form, compatibility studies are one of the most important steps. Drug should not interact with excipients. Our prepared novel superdisintegrant starch malonate should not interact with selected drug. Here, we have performed compatibility studies by FTIR studies, DSC, TLC studies.

\section{Infrared spectroscopy}

FTIR studies were performed by IR Spectroscopy method, using KBr disc as reference. Drug-excipient mixture was prepared in 1:1 ratio and study was performed. FTIR spectra was recorded on samples prepared in potassium bromide (KBr) disks using a BRUKER FT-IR, (Tokyo, Japan). $\mathrm{KBr}$ disks of samples were made at 6-8 tons hydrostatic press and analyzed sample between scanning range 500 to $4000 \mathrm{~cm}^{-1}$.

\section{Differential scanning calorimetry (DSC)}

Thermogram was recorded on Perkin Elmer Thermal Analyser. Thermogram of pure drug (aceclofenac) and excipient drug mixture in 1:1 ratio was recorded and compared.

\section{TLC studies}

Thin layer chromatography (TLC) study

Stationary Phase: Silica gel H (pre-coated TLC plates).

Mobile Phase: Toluene: Ethyl Acetate: Glacial Acetic Acid (17.5:10:0.5)

\section{Procedure}

Mobile phase was prepared as per ratio given and kept in TLC chamber undisturbed for $24 \mathrm{~h}$ in order to saturate the camber. With the help of narrow capillary tube, pure drug, drug with excipient were spotted on the activated silica plate. The spotted plates were kept in the thin layer chromatography (TLC) chamber and allowed to run mobile phase. The plates were dried and kept in iodine chamber to develop the spots. Determine the retardation factor (Rf) by using the formula given below:

Retardation factor $\left(R_{F}\right)=$ Distance travelled by sample/Distance travelled by solvent front.

\section{Preparation of fast dissolving tablets of aceclofenac}

Table 1 gives the formula for the preparation of fast dissolving tablets employing starch malonate. 25 tablets of each formulation were prepared to carry out all the tests. Each ingredient was weighed accurately as per table 1 and screened through mesh \# 120 before mixing, for uniformity in particle size. In a dried mortar pestle all the accurately weighed ingredients were blended to get uniformity in particle size. Fast dissolving tablets was compressed using $10 \mathrm{~mm}$ punches by direct compression method by using by using eight station rotatory press Karnawathi Machineries Pvt, Ltd., Ahmedabad, India).

\section{Evaluation of aceclofenac fast dissolving tablets}

\section{Hardness test}

Hardness determines the tablet strength to withstand wear and tear while transportation and handling. If tablet is getting 
breaking down while transportation or while removing from packing, there is no use. Aceclofenac fast dissolving tablets are determined by using Monsanto hardness tester and expressed in units of $\mathrm{kg} / \mathrm{cm}^{2}[9]$.

Table 1: Formulae of aceclofenac fast dissolving tablets employing starch malonate prepared by direct compression method

\begin{tabular}{|c|c|c|c|c|c|c|c|c|}
\hline Ingredients (mg/tablet) & F1 & F2 & F3 & F4 & F5 & F6 & F7 & F8 \\
\hline Aceclofenac & 100 & 100 & 100 & 100 & 100 & 100 & 100 & 100 \\
\hline Starch Malonate & --- & 25 & --- & 25 & --- & 25 & --- & 25 \\
\hline Croscarmellose sodium & --- & --- & 25 & 25 & --- & -- & 25 & 25 \\
\hline Crospovidone & --- & --- & --- & --- & 25 & 25 & 25 & 25 \\
\hline Mannitol & 130 & 105 & 105 & 80 & 105 & 80 & 80 & 55 \\
\hline Microcrystalline cellulose & 250 & 250 & 250 & 250 & 250 & 250 & 250 & 250 \\
\hline Talc & 10 & 10 & 10 & 10 & 10 & 10 & 10 & 10 \\
\hline Magnesium stearate & 10 & 10 & 10 & 10 & 10 & 10 & 10 & 10 \\
\hline Total & 500 & 500 & 500 & 500 & 500 & 500 & 500 & 500 \\
\hline
\end{tabular}

\section{Uniformity of weight}

Weight variation test tells the variation in the individual weight of tablet from the average weight of 20 tablets. Randomly 20 tablets were selected from each formulation and weight variation test was performed [9].

\section{Friability}

By using Roche friabilator, friability of all tablets was determined. At 25 rpm tablets were rotated for 4 min or up to 100 revolutions [9]. Tablets were weighed again after the removal of fine dust from the tablet surface, and weight loss percentage was calculated by the given formula:

$$
\mathrm{F}=\frac{100 \mathrm{xw} \text { (initial) }-\mathrm{W} \text { (final) }}{\mathrm{W} \text { (initial) }}
$$

\section{Drug content uniformity}

For content uniformity, ten tablets were weighed and powdered a quantity of powder equivalent to $100 \mathrm{mg}$ of aceclofenac was extracted into 7.4 phosphate buffer and filtered. The aceclofenac content was determined by measuring the absorbance spectrophotometrically at 274 $\mathrm{nm}$ after appropriate dilution with 7.4 phosphate buffer. The drug content was calculated as an average of three determinations.

\section{Wetting time}

Five pieces of circular tissue paper were placed in Petri plate having $10 \mathrm{~cm}$ diameter. Ten $\mathrm{ml}$ of water containing a water-soluble dye (amaranth) was added to the petri dish. Carefully one tablet was kept in the petri plate in and the time taken by colored water to reach the upper surface of the tablet was noted as wetting time [10].

\section{Water absorption ratio}

The tissue paper was folded twice as per the diameter of the petri dish and $6 \mathrm{ml}$ of water was added to the petri dish. A tablet was kept on the tissue paper and allowed to wet thoroughly and the wetted tablet was weighed. Water absorption ratio was calculated by using the given Equation:

$$
R=\frac{100\left(\mathrm{~W}_{\mathrm{d}}-\mathrm{W}_{\mathrm{e}}\right)}{W_{e}}
$$

Where,

\section{$\mathrm{W}_{\mathrm{d}}=$ Tablet weight after water absorption \\ $\mathrm{W}_{\mathrm{e}}=$ Tablet weight before water absorption}

\section{In-vitro disintegration time}

A disintegration time study was performed using USP disintegration apparatus having $\mathrm{pH} 7.4$ phosphate buffer as dissolution medium maintained at $37 \pm 0.2{ }^{\circ} \mathrm{C}$. Time in seconds noted required for complete disintegration of the tablets with no palatable mass left in the apparatus [11].

\section{In-vitro dissolution studies}

The in vitro dissolution studies of aceclofenac fast dissolving tablets were performed using 8 stage dissolution test apparatus (Electrolab
TDT-08L) fitted with paddles ( $50 \mathrm{rpm}$ ) at $37 \pm 0.50 \mathrm{C}$, using $\mathrm{pH} 7.4$ phosphate buffer $(900 \mathrm{ml})$ as a dissolution media. At defined time intervals, $5 \mathrm{ml}$ samples were withdrawn, filtered through a $0.45 \mu$ membrane filter, diluted and assayed at $274 \mathrm{~nm}$ using a schimadzu UV/Visible double beam spectrophotometer. Cumulative percentage drug dissolution was measured using standard absorbance from the calibration curve [11]. In vitro dissolution experiments were conducted in triplicate $(\mathrm{n}=3)$

\section{Stability studies}

As per ICH stability guidelines, stability studies were performed to check the changes in the quality of a drug substance or drug product with time with respect to various environmental factors like temperature, humidity and light stability. Stability studies of F2 formulation was carried out. The tablets were packed in screw capped HDPE bottles and were stored at $40^{\circ} \mathrm{C} \pm 2{ }^{\circ} \mathrm{C}$ and $75 \% \mathrm{RH}$ for $6 \mathrm{mo}$. After storage for $6 \mathrm{mo}$, the products were tested for drug content and drug dissolution rate [11].

\section{RESULTS AND DISCUSSION}

The starch malonate prepared was found to be fine, free flowing slightly crystalline powder. The physical and micromeritics properties of the starch malonate are summarized in table 2. It was insoluble in aqueous solvents and insoluble in organic solvents tested (methanol, petroleum ether, dichloromethane, and chloroform). The $\mathrm{pH}$ of $0.1 \%$ aqueous dispersion was 3.15. Starch malonate exhibited good swelling in water. The swelling index was $83.95 \%$. All micrometric properties indicated good flow and compressibility needed for solid dosage form manufacturing. The density of starch malonate was found to be 1.008 $\mathrm{g} / \mathrm{cc}$. The angle of repose and compressibility index showed good flow properties of starch malonate.

\section{Table 2: Physical and micromeritics properties of the starch} malonate

\begin{tabular}{ll}
\hline Parameters & Observation \\
\hline Solubility & $\begin{array}{l}\text { Insoluble in all aqueous and organic } \\
\text { solvents tested }\end{array}$ \\
$\mathrm{pH}(1 \% \mathrm{w} / \mathrm{v}$ aqueous & 3.15 \\
dispersion) & \\
Melting Point & Charred at $270{ }^{\circ} \mathrm{C}$ \\
Viscosity (1\% w/v & $1.022 \mathrm{cps}$ \\
aqueous dispersion) & \\
Swelling index & $83.95 \%$ \\
Gelling property & No gelling at $100^{\circ} \mathrm{C}$ but formed a clear \\
& solution. Whereas in the case of starch, \\
& it was gelatinized and formed gel. \\
Particle Size & $5.78 \pm 2.304 \mu \mathrm{m}(120$ mesh $)$ \\
Density & $1.008 \mathrm{~g} / \mathrm{cc}$ \\
Bulk Density & $0.718 \mathrm{~g} / \mathrm{cc}$ \\
Angle of Repose & $14.6 \pm 0.05$ \\
Compressibility Index & $23.02 \pm 0.03 \%$ \\
\hline
\end{tabular}

FTIR spectra of potato starch and starch malonate are showed in fig. 1 and fig. 2. The presence of peak absorption at $1736.63 \mathrm{~cm}-1$, 
characteristic peak of ester, observed only in the FTIR spectrum of starch malonate and is absent in the FTIR spectrum of potato starch So from FTIR studies it was concluded that starch malonate (ester) was formed when potato starch was allowed to react with malonic acid. The disappearance of pink colour in the ester test confirmed the presence of ester, i.e., starch malonate.

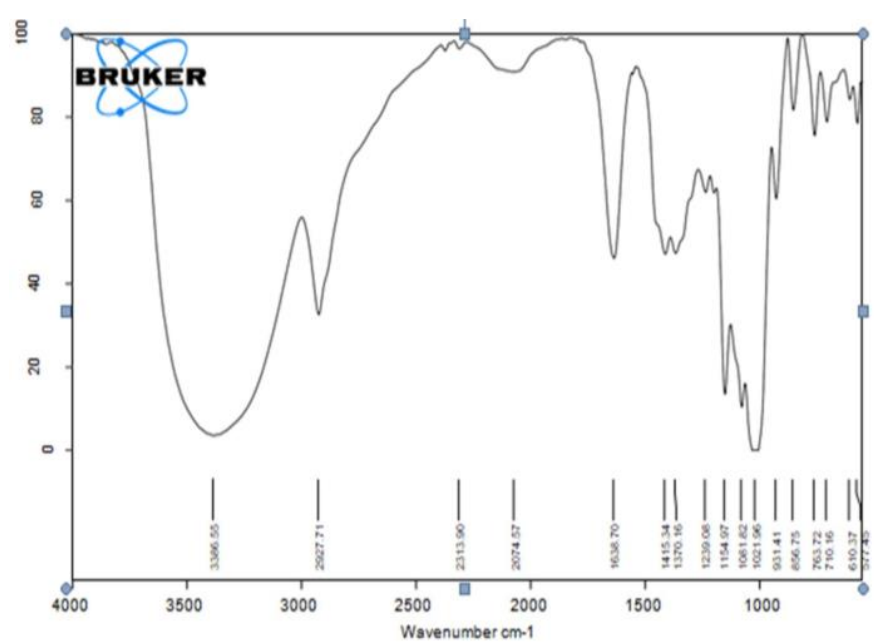

Fig. 1: FTIR spectra of potato starch

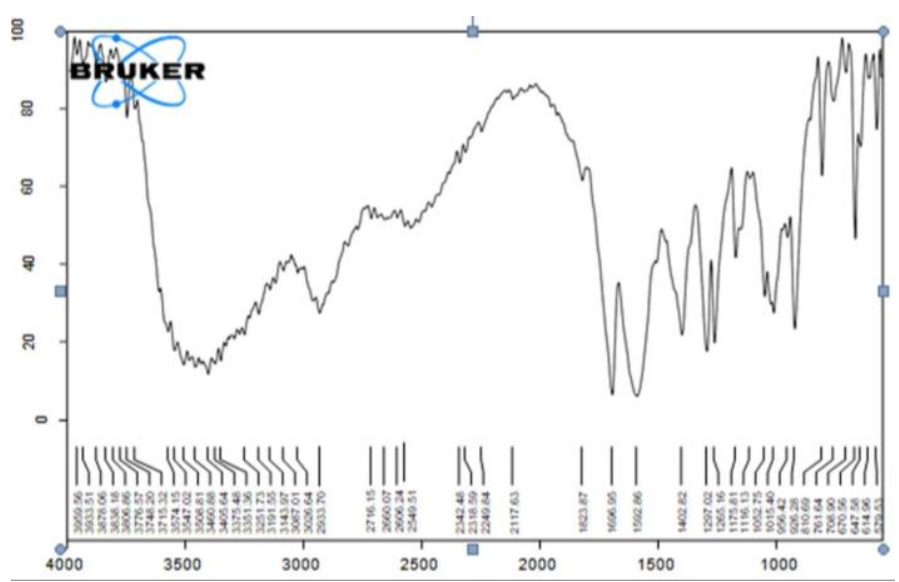

Fig. 2: FTIR spectra of starch malonate

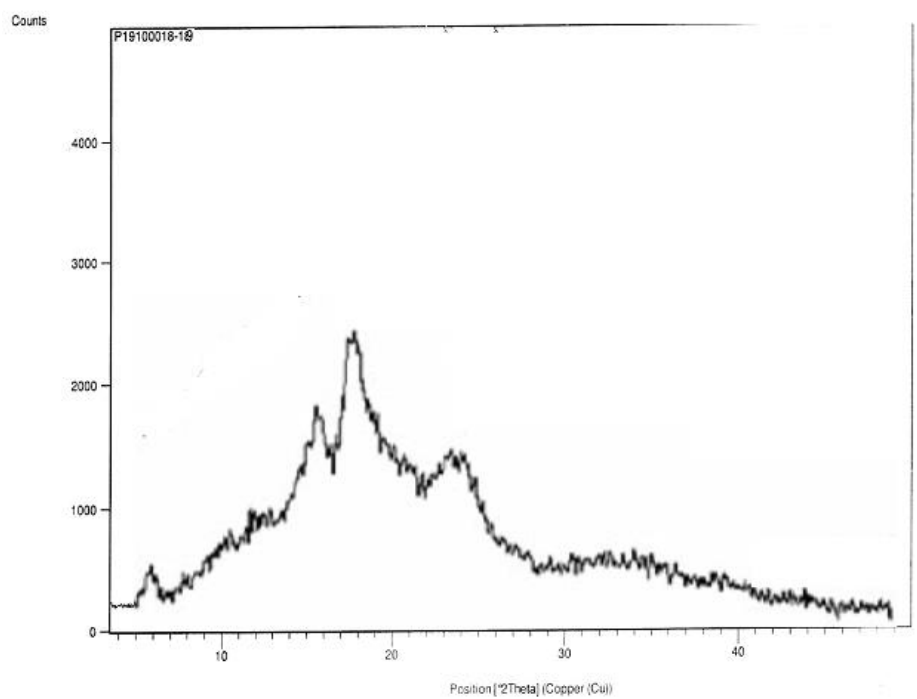

Fig. 3: X-Ray diffraction of potato starch 


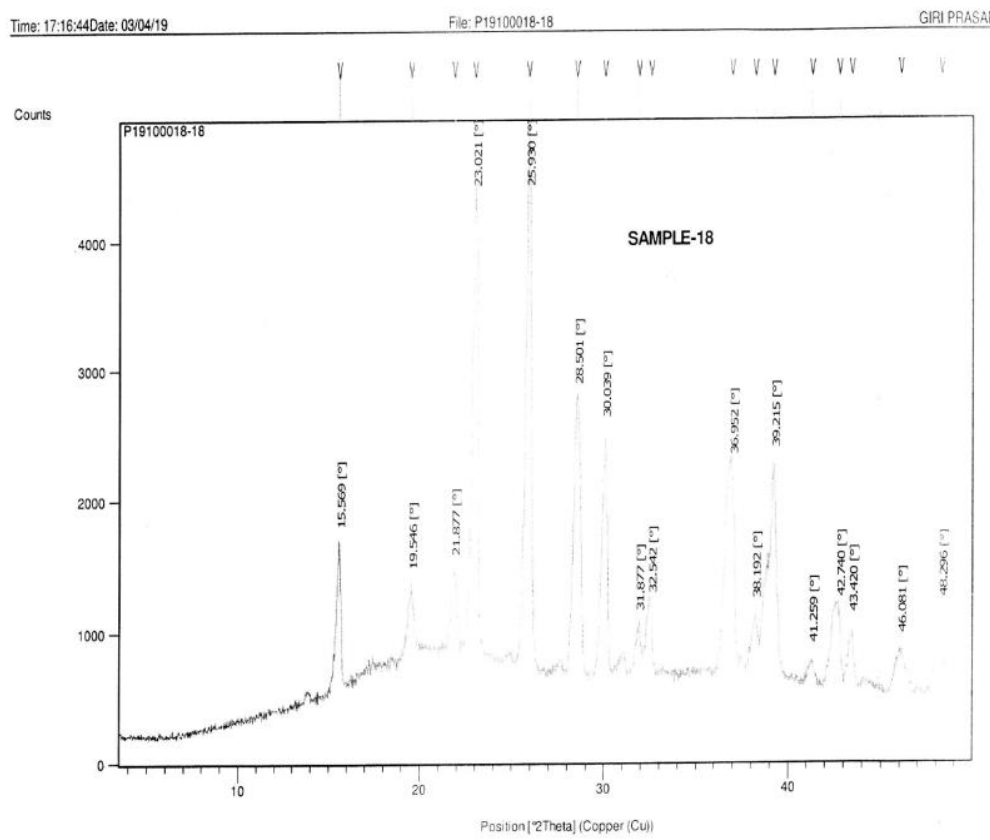

Fig. 4: X-Ray diffraction of starch malonate
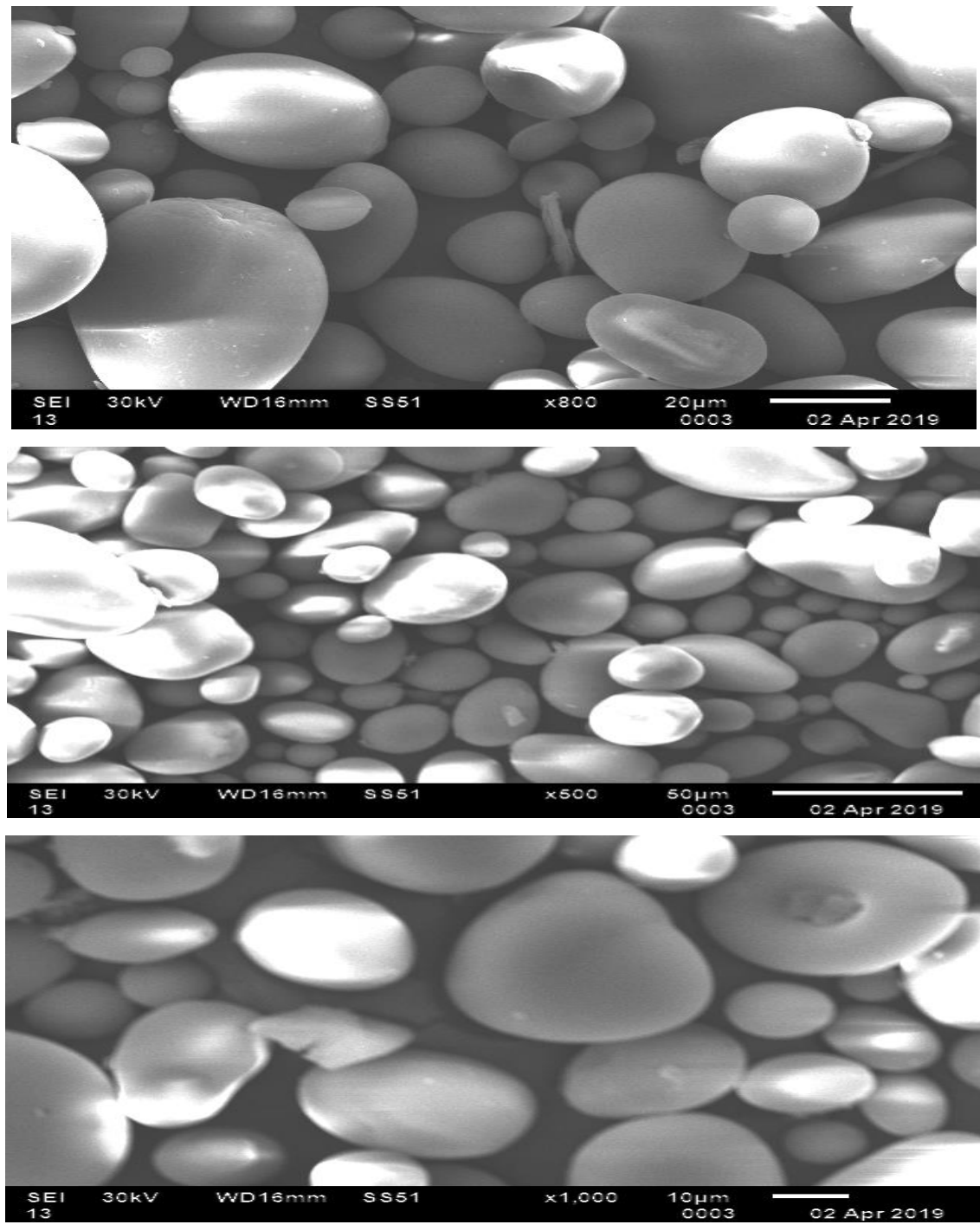

Fig. 5: Scanning electron microscopy of potato starch 
The X-ray diffraction pattern of starch and starch malonate given in fig. 3 and 4. Fig. 4 i.e., starch malonate showed small characteristic peaks, which indicates that the structure is slightly crystalline in nature which are absent in potato starch (fig. 3) indicating the amorphous nature of potato starch. The scanning electron microscopy of the prepared starch malonate also confirmed its crystalline nature. Scanning electron microscopic image of potato starch and starch malonate showed in fig. 4 and fig. 5. Prepared starch malonate was slightly crystalline powder having all the characteristic of superdisintegrant. The swelling index of the starch malonate was found to be $83.95 \%$ indicating that the starch malonate was highly swellable and helps in faster disintegration of the tablet. So, it was concluded that starch malonate can be used as novel superdisintegrant.
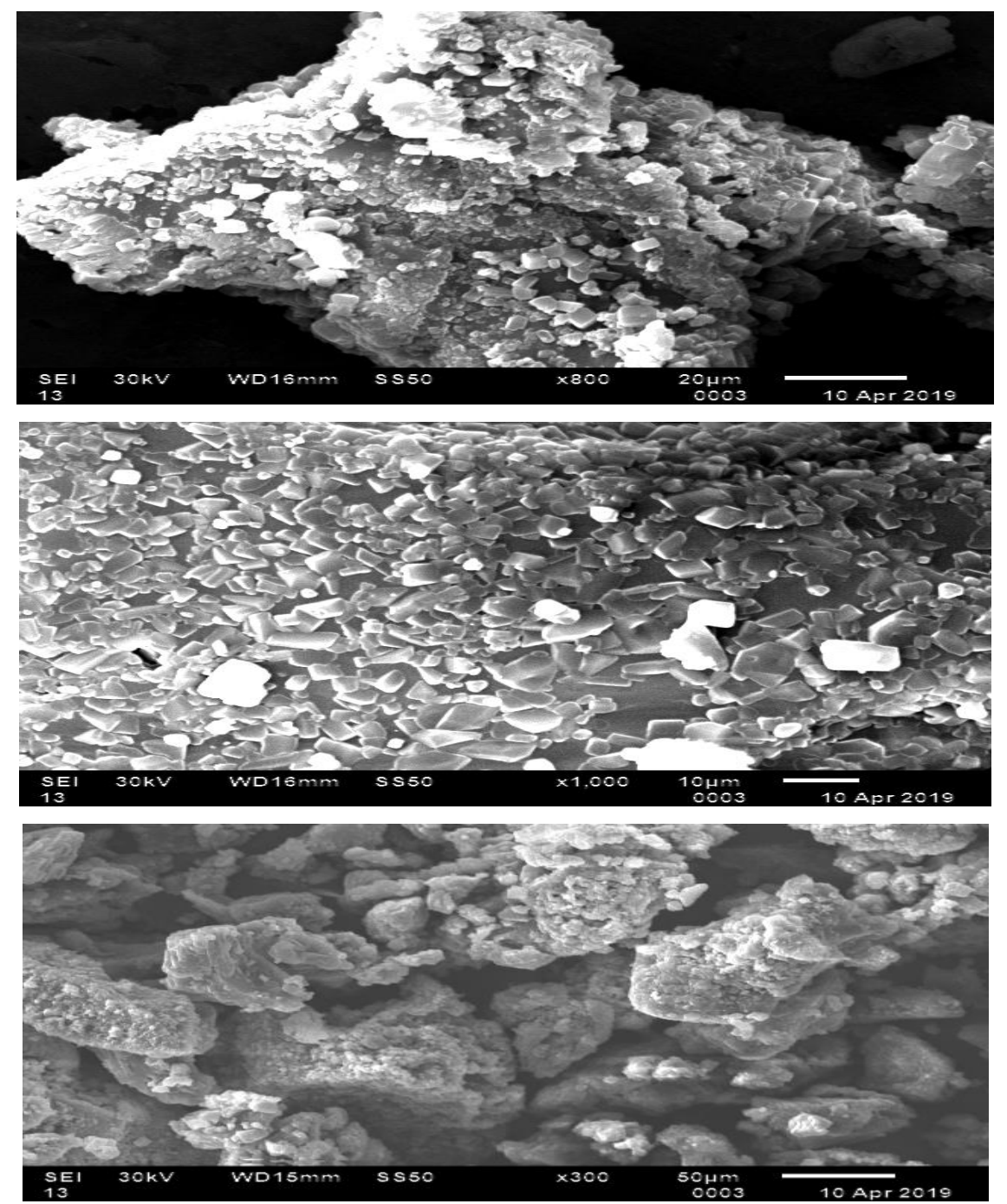

Fig. 6: Scanning electron microscopy of starch malonate

\section{Drug excipient compatibility studies}

The compatibility of starch malonate with the selected drug (aceclofenac) was evaluated by FTIR, differential scanning calorimetry (DSC) and TLC.

The FTIR spectra of aceclofenac and aceclofenac-starch malonate are shown in fig. 6 and 7. The characteristic peak of- $\mathrm{OH}, \mathrm{C}=\mathrm{O}, \mathrm{C}-\mathrm{H}$, $\mathrm{C}=\mathrm{C}$, NH present in FTIR spectra of aceclofenac and aceclofenac plus starch malonate given in table 3 . FTIR spectrum of the Aceclofenac showed characteristic bands at $1718.17(-\mathrm{C}=0)$, $1580.55(-\mathrm{C}=\mathrm{C}), \quad 2968.92 \quad(-\mathrm{OH}), \quad 3317.30 \quad(-\mathrm{NH})$ and 747.44(Aromatic-Cl) whereas in the FTIR spectrum of aceclofenacstarch glutamate exhibited same characteristic bands at $1716.07(-$ $\mathrm{C}=0), 1585.10(-\mathrm{C}=\mathrm{C}), 2970.70(-\mathrm{OH}), 3317.36(-\mathrm{NH})$. From the FTIR spectra, it was concluded that starch malonate did not show any interaction with the selected drug.

Table 3: Characteristic peak present in aceclofenac and aceclofenac plus starch malonate

\begin{tabular}{llll}
\hline \multicolumn{2}{l}{ Functional group } & Characteristic peak present in aceclofenac & Characteristic peak present in aceclofenac plus starch malonate \\
\hline- & OH & 2968.92 & 2970.70 \\
- & C=O & 1718.17 & 1716.07 \\
- & C-H & 2934.01 & 2936.44 \\
- & C=C & 1580.55 & 1585.10 \\
- & NH & 3317.30 & 3317.36 \\
\hline
\end{tabular}




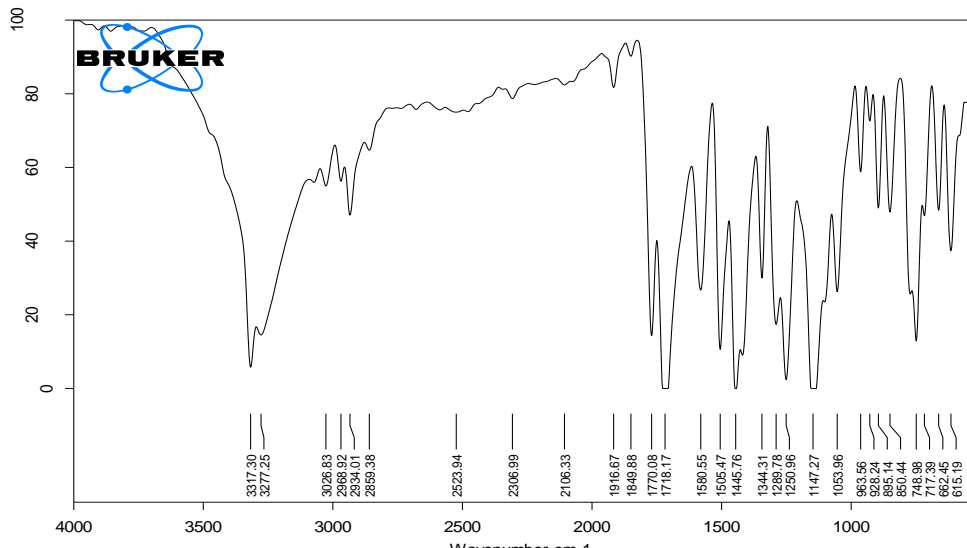

Fig. 7: FTIR spectra of aceclofenac pure drug

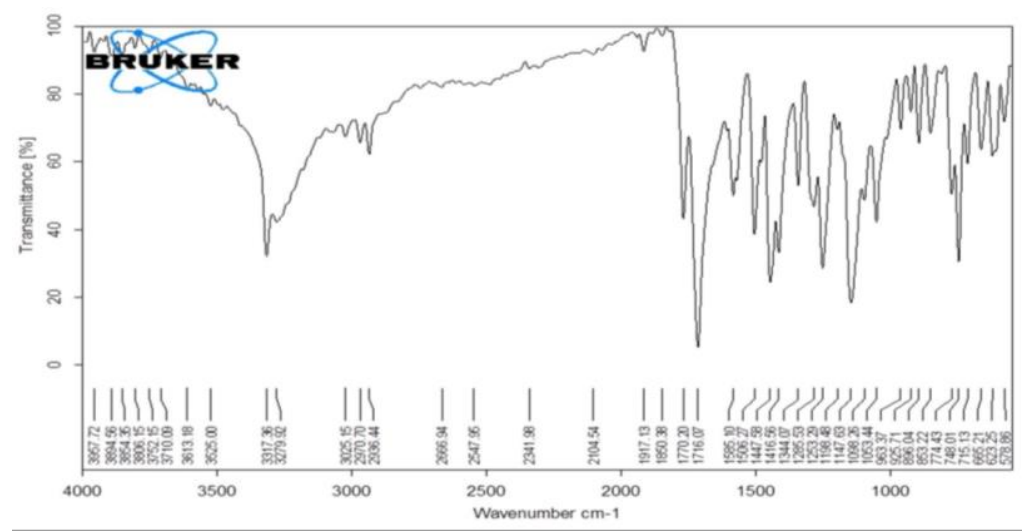

Fig. 8: FTIR spectra of aceclofenac with starch malonate

The DSC thermograms of aceclofenac and aceclofenac-starch malonate are shown in fig. 8 and 9. The DSC thermograms of aceclofenac and aceclofenac-starch malonate exhibited exothermic peaks at $152.57^{\circ} \mathrm{C}$ and $150.35^{\circ} \mathrm{C}$ respectively. These melting peaks of aceclofenac and aceclofenac-starch malonate correspond to the melting points of aceclofenac $\left(145^{\circ} \mathrm{C}-165^{\circ} \mathrm{C}\right)$. The peaks observed in the DSC thermograms of aceclofenac and aceclofenac-starch malonate mixtures correspond to the melting points of the respective drug indicating no interactions between the selected drug and starch malonate. Thus, the differential scanning calorimetry studies indicated no interaction between starch malonate and selected drug.

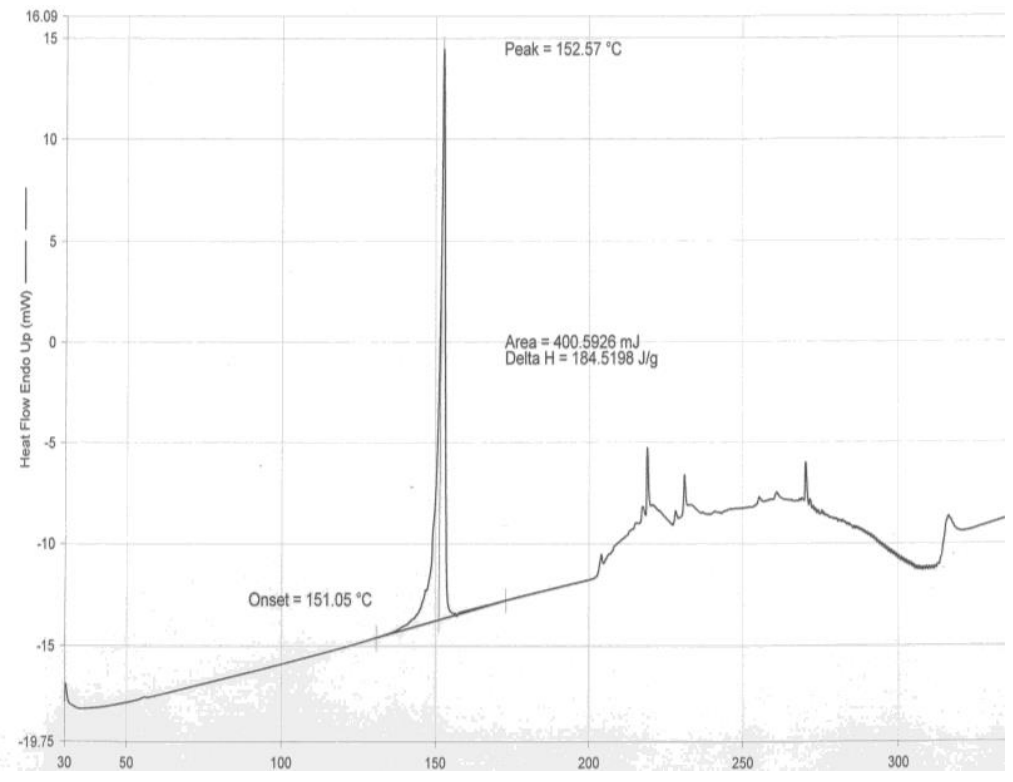

Fig. 9: DSC Thermo gram of aceclofenac pure drug 


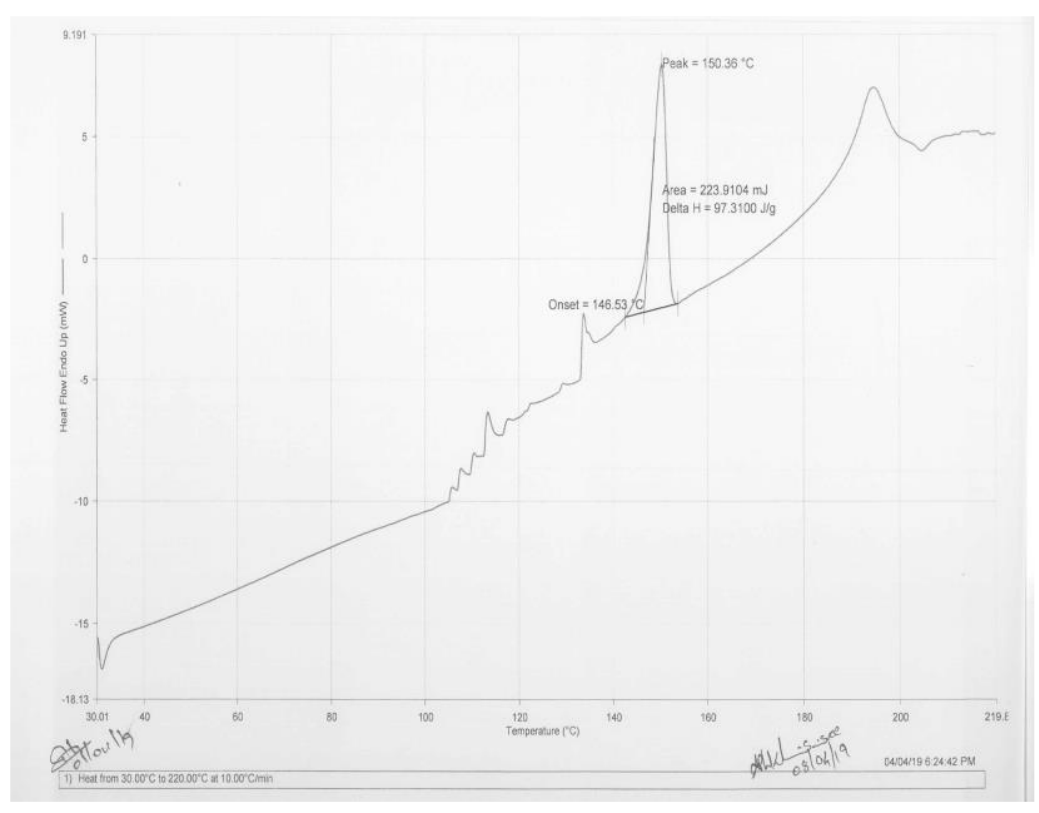

Fig. 10: DSC Thermo gram of aceclofenac with starch malonate

Thin layer chromatography (TLC) plate of aceclofenac and aceclofenac-starch malonate is shown in fig. 10. Aceclofenac and aceclofenac with starch malonate observed as single spot. Retardation factor (Rf) of aceclofenac (0.5) and mixture of aceclofenac with starch malonate (0.507) are close indicates that there was no interaction between drug and starch malonate.

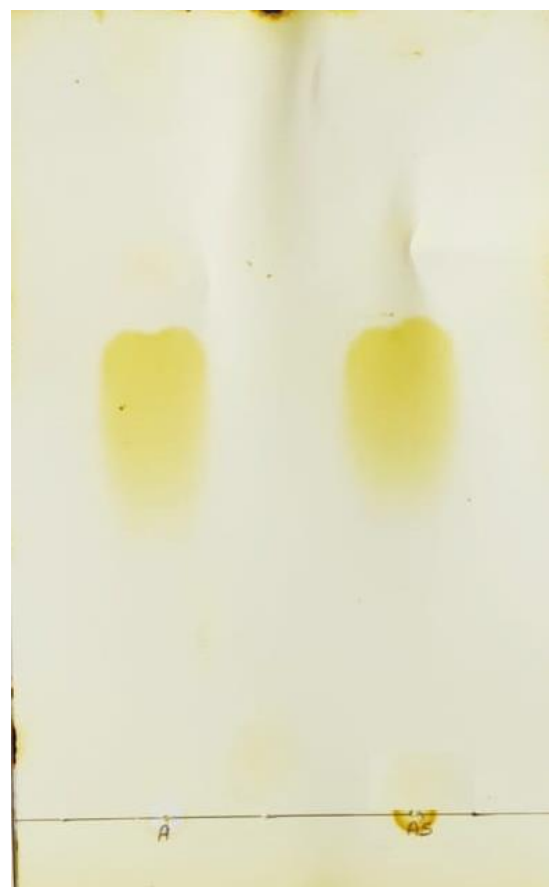

Fig. 11: A) Thin layer chromatography (TLC) plate showing (A) Aceclofenac pure drug (B) Aceclofenac and starch malonate

\section{Hardness}

Hardness of fast dissolving tablets of Aceclofenac from all batches was found to be in the range of $3.8-4.2 \mathrm{~kg} / \mathrm{cm}^{2}$. All the formulations prepared employed using starch malonate as superdisintegrant possess sufficient hardness to withstand stress during handling, transportation and storage.

\section{Friability}

All the formulation tablets passed the official IP test and possess friability between $0.11 \pm 0.011$ to $0.14 \pm 0.011$. Weight loss in the friability test was less than $0.15 \%$ in all formulations. As per IP, percent friability below $1 \%$ is an indication of good mechanical resistance of the tablets. Thus, it was proved that tablets could withstand the pressure, mechanical shocks during handling, transportation, storage and manufacturing processes.

\section{Drug content uniformity}

Drug content of all the formulation tablets was found to be within $97.58 \pm 0.71$ to $99.56 \pm 0.57 \mathrm{mg} /$ tablet of the labeled amount. All the formulations are having an accurate amount of drug distributed uniformly and followed acceptable limits as per IP. Drug content uniformity results were tabulated in table 4 .

\section{In vitro disintegration time}

The disintegration time of all the formulated tablets were tabulated in table 4 and found to be in the range of 38 to 2000 seconds. The disintegration time of the formulated tablets depends on the concentration of superdisintegrant used. The formulation containing no superdisintegrant was found to have more disintegration time as compared to other formulations. Formulation F2 containing novel prepared superdisintegrant i. e starch malonate was found to have least disintegration time of 38 seconds whereas formulation F8 containing $5 \%$ of three superdisintegrant croscarmellose sodium, crospovidone and starch malonate showed disintegration time 49 seconds. The novel prepared superdisintegrant has showed least disintegration time when used alone and in combination as compared aceclofenac fast dissolving tablets prepared employing sodium starch glycolate, croscarmellose sodium and crospovidone by Wagh et al. and aceclofenac tablets prepared employing $\beta C D$ and Kolliphor HS15 by Chowdary et al. [12,13]

\section{Water absorption ratio and wetting time}

The water absorption ratio was in between $79.6 \pm 0.14$ to $148 \pm 0.20$. The wetting time found between $17 \pm 0.08-80 \pm 0.05$ seconds. Results of water absorbtion ratio and wetting time of all formulations are given in table 4 and wetting time of aceclofenac fast dissolving tablet are shown in fig. 11 and fig. 12. Formulation F2containing starch malonate alone and formulation F8 containing starch malonate in combination showed less wetting time and more water absorption ratio as compared to other formulations. The wetting time and water absorbtion ratio was found to be good as compared to aceclofenac fast dissolving tablets employing different concentrations of Lepidium sativum mucilage as natural superdisintegrant by Kaur et al. [14] 
Table 4: Showing results of different evaluation parameters of aceclofenac fast dissolving tablets

\begin{tabular}{|c|c|c|c|c|c|c|}
\hline Formulation & $\begin{array}{l}\text { Hardness } \\
\left(\mathrm{Kg} / \mathrm{Cm}^{2}\right) \mathrm{n} \pm \mathrm{SD}\end{array}$ & $\begin{array}{l}\text { Friability } \\
(\%) n \pm S D\end{array}$ & $\begin{array}{l}\text { Drug content } \\
(\mathrm{mg} / \mathrm{tab}) \mathrm{n} \pm \mathrm{SD}\end{array}$ & $\begin{array}{l}\text { Disintegration } \\
\text { time (sec) } n \pm S D\end{array}$ & $\begin{array}{l}\text { Wetting time } \\
\text { (sec) } n \pm S D\end{array}$ & $\begin{array}{l}\text { Water absorption } \\
\text { ratio (\%) } n \pm S D\end{array}$ \\
\hline F1 & $4.2 \pm 0.01$ & $0.13 \pm 0.011$ & $97.58 \pm 0.71$ & $2000 \pm 0.014$ & $80 \pm 0.05$ & $79.6 \pm 0.14$ \\
\hline F2 & $4.0 \pm 0.03$ & $0.12 \pm 0.010$ & $98.10 \pm 0.79$ & $38 \pm 0.02$ & $17 \pm 0.08$ & $140.9 \pm 0.017$ \\
\hline F3 & $3.9 \pm 0.01$ & $0.11 \pm 0.011$ & $99.45 \pm 0.63$ & $60 \pm 0.07$ & $47 \pm 0.03$ & $137 \pm 0.20$ \\
\hline F4 & $3.8 \pm 0.04$ & $0.11 \pm 0.012$ & $98.56 \pm 0.55$ & $55 \pm 0.04$ & $29 \pm 0.015$ & $139 \pm 0.13$ \\
\hline F5 & $3.9 \pm 0.04$ & $0.13 \pm 0.010$ & $99.23 \pm 0.56$ & $295 \pm 0.01$ & $53 \pm 0.011$ & $80.9 \pm 0.011$ \\
\hline $\mathrm{F} 6$ & $3.9 \pm 0.01$ & $0.14 \pm 0.011$ & $99.34 \pm 0.18$ & $305 \pm 0.03$ & $18 \pm 0.14$ & $143 \pm 0.010$ \\
\hline F7 & $3.9 \pm 0.02$ & $0.13 \pm 0.011$ & $99.56 \pm 0.57$ & $305 \pm 0.05$ & $35 \pm 0.10$ & $126 \pm 0.18$ \\
\hline F8 & $4.0 \pm 0.04$ & $0.12 \pm 0.012$ & $99.17 \pm 0.11$ & $49 \pm 0.011$ & $26 \pm 0.05$ & $148 \pm 0.20$ \\
\hline $\begin{array}{l}\text { Marketed } \\
\text { formulation }\end{array}$ & $3.9 \pm 0.01$ & $0.15 \pm 0.012$ & $99.12 \pm 0.11$ & $14 \pm 0.04$ & $23 \pm 0.19$ & $75 \pm 0.27$ \\
\hline
\end{tabular}

*SD Standard Deviation from mean, $\mathrm{n}=3$

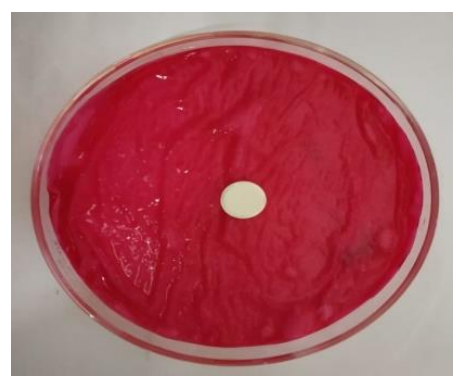

F1 at $\mathrm{T}=0 \mathrm{sec}$

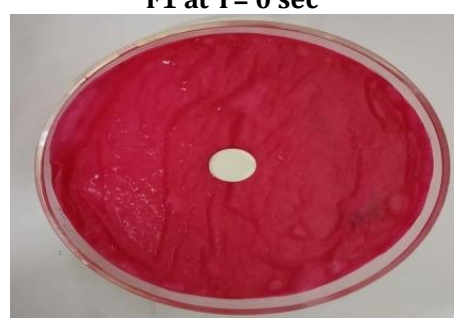

F2 at $\mathrm{T}=0 \mathrm{Sec}$

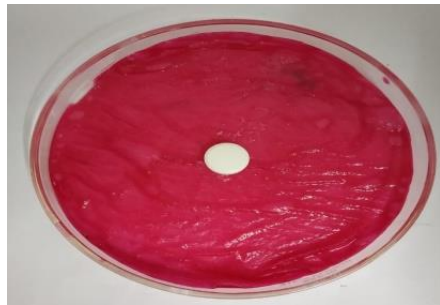

F3 at $\mathbf{T}=\mathbf{0}$

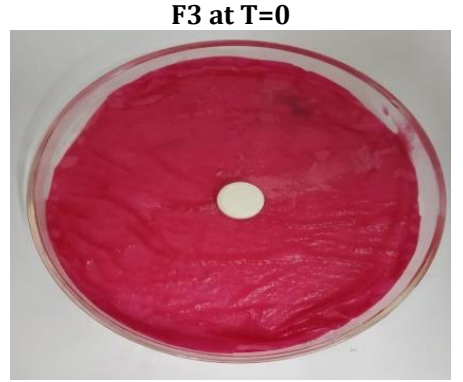

F4 at $T=0$

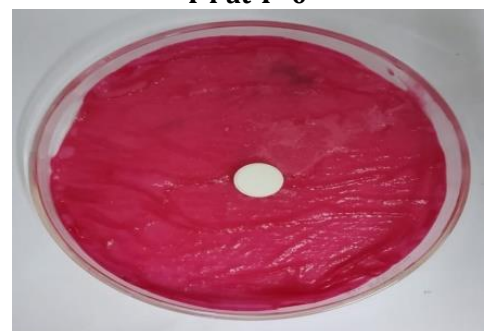

F5 at $\mathbf{T}=0$

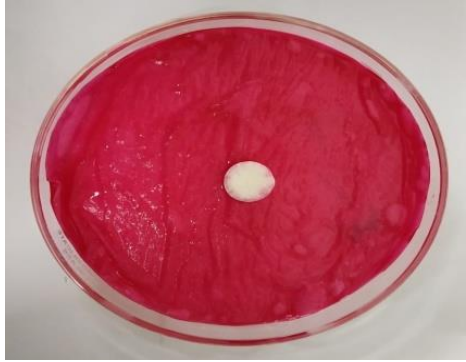

F1 at $\mathbf{T}=80$ seconds

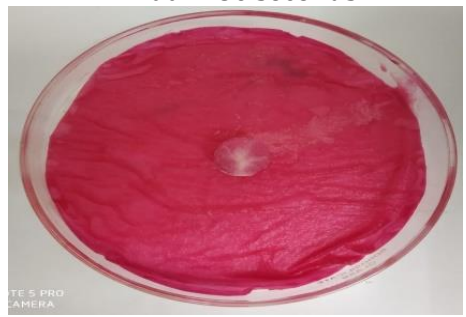

$\mathrm{F} 2$ at $\mathrm{T}=17$ seconds

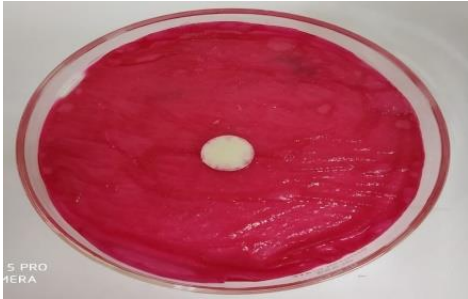

F3 at $\mathrm{T}=\mathbf{4 7}$ seconds

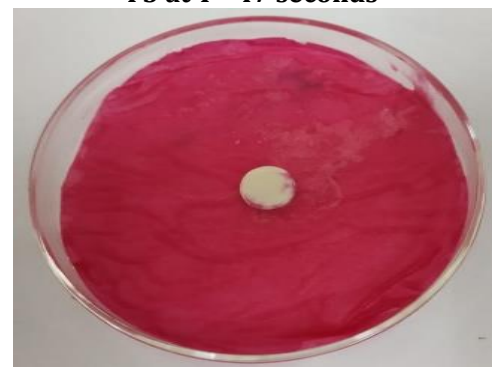

F4 at $\mathrm{T}=29$ seconds

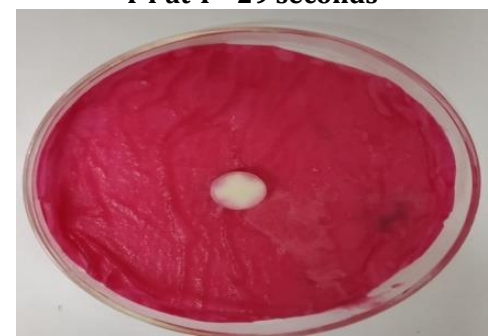

F5 at $\mathrm{T}=53$ seconds

Fig. 12: Formulation F1 to F5 wetting time (Starch malonate employing fast dissolving tablets) 


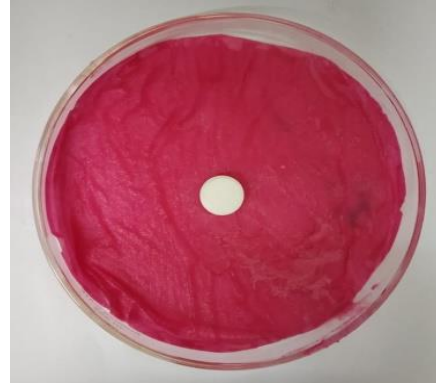

F6 at $\mathrm{T}=0$

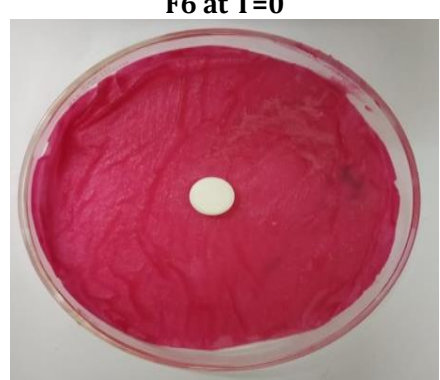

$+\mathrm{F} 7$ at $\mathrm{T}=0$

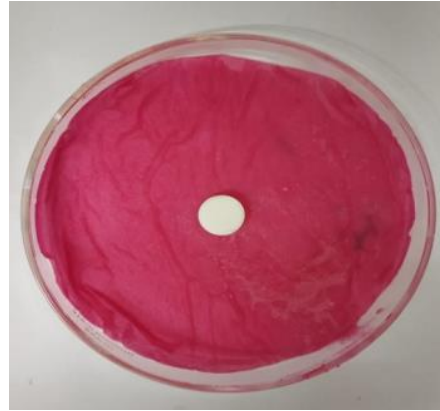

F8 at $\mathrm{T}=0$

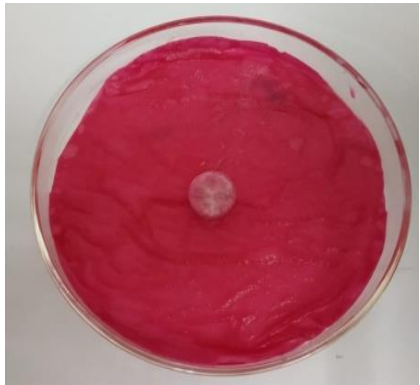

F6 at $T=18$ seconds

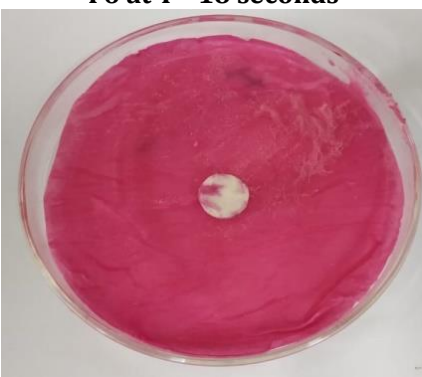

F7 at $\mathrm{T}=35$ seconds

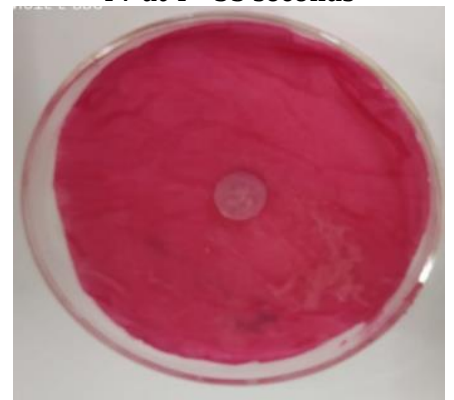

F8 at $\mathrm{T}=26$ seconds

Fig. 13: Formulation F6 to F8 wetting time (Starch malonate employing fast dissolving tablets)

\section{In vitro dissolution studies}

USP Type II Paddle apparatus was used to conduct dissolution study. Dissolution rate of fast dissolving tablet is inversely related to wetting time of the tablet. Optimized formulation F2 containing starch malonate alone has showed enhanced drug dissolution and least wetting time as compared to other formulations. Formulation (F2) contains $5 \%$ of starch malonate alone as disintegrant has showed enhanced drug dissolution (99.84\%) as equivalent to formulation (F8) showed $99.94 \%$ containing combination of superdisintegrants (starch malonate, croscarmellose sodium and crospovidone). Optimized formulation F2 was found better and showed enhanced drug dissolution than aceclofenac fast dissolving tablets formulation prepared by Kumar et al. and by Hazarika et al. $[15,16]$.

This indicated that starch malonate can be used as a superdisintegrant to enhance the drug dissolution of poorly soluble drugs. Dissolution profiles of all the formulations are shown in fig. 13. Same results have been observed in case of DE5\%, dissolution efficiency in 5 min are highest in formulation F2 and F8. Hence, it can be understood that F2 is the best formulation as it contains only starch malonate as superdisintegrant and showed enhanced drug dissolution as compared to other formulation contains combination of superdisintegrant.

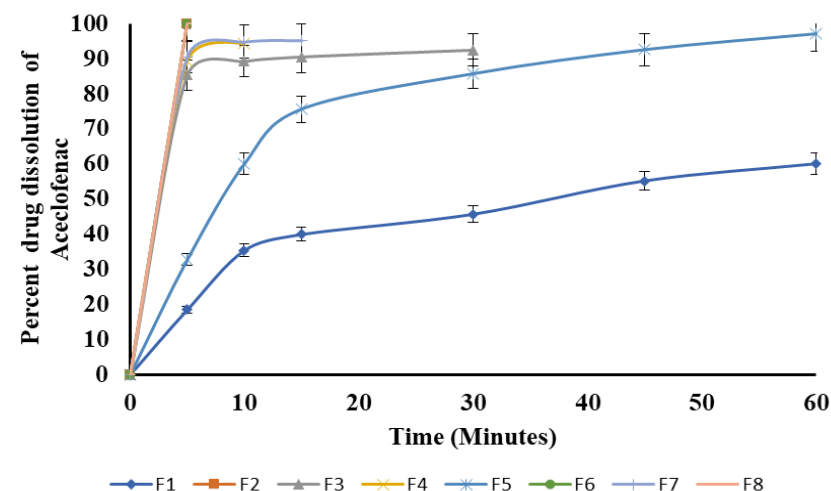

Fig. 14: Dissolution profiles of aceclofenac fast dissolving tablets prepared employing starch malonate (F1-F8) (n $=3$, mean \pm SD) 
Table 5: Dissolution parameters of aceclofenac fast dissolving tablets formulated employing starch malonate

\begin{tabular}{|c|c|c|c|c|c|c|c|c|c|}
\hline Time (min) & F1 & F2 & F3 & F4 & F5 & F6 & F7 & F8 & $\begin{array}{l}\text { M Marketed } \\
\text { formulation }\end{array}$ \\
\hline PD5 & $118.5 \pm 0.05$ & $99.84 \pm 0.09$ & $85.37 \pm 0.02$ & $89.26 \pm 0.06$ & $32.78 \pm 0.08$ & $99.87 \pm 0.03$ & $90.56 \pm 0.07$ & $99.94 \pm 0.02$ & $73.68 \pm 0.13$ \\
\hline DE $5 \%$ & $11.5 \pm 0.04$ & $94 \pm 0.05$ & $78.7 \pm 0.04$ & $84.1 \pm 0.04$ & $26.1 \pm 0.04$ & $93.9 \pm 0.05$ & $83.6 \pm 0.07$ & $94.3 \pm 0.04$ & $7.4 \pm 0.19$ \\
\hline $\begin{array}{l}\text { No. of folds } \\
\text { increase in DE5\% }\end{array}$ & --- & $8.18 \pm 0.02$ & $6.84 \pm 0.04$ & $7.313 \pm 0.09$ & $2.26 \pm 0.05$ & $8.165 \pm 0.02$ & $7.269 \pm 0.03$ & $8.2 \pm 0.04$ & ---- \\
\hline
\end{tabular}

*SD standard deviation from mean, $\mathrm{n}=3$, PD5--percent dissolved in 5 min., DE5\%-dissolution efficiency in 5 min

To evaluate the individual and combined effects of the three factors (starch malonate, croscarmellose sodium and crospovidone) involved in the preparation of fast dissolving tablets employing selected combinations of the factors as per 23factorial design. The fast dissolving tablets and drug dissolution parameters (percent drug dissolved in $5 \mathrm{~min}$ ) of the fast dissolving formulated were analyzed as per ANOVA of 23 -factorial design.

ANOVA of fast disintegrating times (table 6), ANOVA of percent dissolved in $5 \mathrm{~min}$ (table 7), ANOVA of wetting time (table 8), ANOVA of water absorption ratio (table 9) and ANOVA of dissolution efficiency in 5 min (table 10) indicated that the individual effects of starch malonate (A), sodium starch glycolate (B) and crospovidone (C) as well as the combined effects of $\mathrm{AB}, \mathrm{AC}, \mathrm{BC}$ and $\mathrm{ABC}$ factors were significant $(\mathrm{P}<0.05)$ on disintegration time, percent dissolved in 5 min, wetting time, water absorption ratio and dissolution efficiency in 5 min of aceclofenac fast dissolving tablets.

Fast dissolving tablets formulated employing starch malonate (5\%) as superdisintegrant exhibited faster disintegration, more percent drug dissolution in $5 \mathrm{~min}$, less wetting time, more water absorption ratio and more dissolution efficiency in 5 min. On comparison with the marketed formulation, the optimized F2 formulation gave drug dissolution of $99.84 \%$ in 5 min fulfilling the official specification based on the disintegration time, percent drug dissolved in $5 \mathrm{~min}$, wetting time, water absorption ratio and dissolution efficiency in $5 \mathrm{~min}$.

The results of disintegration time, percent drug dissolved in $5 \mathrm{~min}$, wetting time, water absorption ratio and dissolution parameters like dissolution efficiency in $5 \mathrm{~min}$ indicated that the optimized formulation F2 gave better results as close to marketed formulation.

Table 6: ANOVA of disintegration time of aceclofenac fast dissolving tablets formulated employing starch malonate

\begin{tabular}{|c|c|c|c|c|c|c|}
\hline Source of variance & $\begin{array}{l}\text { Degree of } \\
\text { freedom }\end{array}$ & Sum square & $\begin{array}{l}\text { Mean sum square (sum } \\
\text { square/d. f) }\end{array}$ & $\begin{array}{l}\text { Variation ratio(f) } \\
\text { (mss/mss error) }\end{array}$ & F ratio & $\begin{array}{l}\text { Significant/ } \\
\text { non-significant }\end{array}$ \\
\hline Replicates & 2 & 18.25 & 9.125 & 1.334203655 & 2.77 & $\mathrm{P}<0.05$ \\
\hline Treatments & 7 & 9242255 & 1320322.143 & 193049.7128 & 4.66 & $\mathrm{P}<0.05$ \\
\hline No superdisintegrant & 1 & 3616161 & 3616161 & 528733.7232 & 4.66 & $\mathrm{P}<0.05$ \\
\hline Starch malonate (A) & 1 & 1837067 & 1837067 & 268605.0966 & 4.66 & $\mathrm{P}<0.05$ \\
\hline Croscarmellose sodium (B) & 1 & 1763668 & 358.8267 & 52.46552272 & 4.66 & $\mathrm{P}<0.05$ \\
\hline $\begin{array}{l}\text { Starch malonate } \mathrm{X} \\
\text { Croscarmellose sodium (AB) }\end{array}$ & 1 & 1074420 & 1074420 & 157095.3525 & 4.66 & $\mathrm{P}<0.05$ \\
\hline Crospovidone (C) & 1 & 542402.7 & 542402.7 & 79306.92219 & 4.66 & $\mathrm{P}<0.05$ \\
\hline $\begin{array}{l}\text { Starch malonate } \mathrm{X} \\
\text { crospovidone }(\mathrm{AC})\end{array}$ & 1 & 1112843 & 1112843 & 162713.3368 & 4.66 & $\mathrm{P}<0.05$ \\
\hline $\begin{array}{l}\text { Croscarmellose sodium X } \\
\text { crospovidone (BC) }\end{array}$ & 1 & 1055882 & 1055882 & 154384.8355 & 4.66 & $\mathrm{P}<0.05$ \\
\hline $\begin{array}{l}\text { Starch malonate X } \\
\text { croscarmellose sodium X } \\
\text { crospovidone (ABC) }\end{array}$ & 1 & 1855928 & 1855928 & 271362.8407 & 4.66 & $\mathrm{P}<0.05$ \\
\hline Error & 14 & 95.75 & 6.839285714 & & & \\
\hline Total & 23 & 9242369 & & & & \\
\hline
\end{tabular}

$\mathrm{P}<0.05$ indicate significance; $\mathrm{p}>0.05$ indicate non-significance, d. f-Degree of Freedom * S. S-Sum of Square * M. S. S-Mean Sum of Squares, All the values are expressed as mean $\pm S D$, where $n=3$, SD: Standard Deviation, ANOVA-Analysis of Variance

Table 7: ANOVA of percent dissolved in $\mathbf{5}$ min of aceclofenac fast dissolving tablets formulated employing starch malonate

\begin{tabular}{|c|c|c|c|c|c|c|}
\hline Source of variance & $\begin{array}{l}\text { Degree of } \\
\text { freedom }\end{array}$ & Sum square & $\begin{array}{l}\text { Mean sum square } \\
\text { (sum square/d. f) }\end{array}$ & $\begin{array}{l}\text { Variation ratio (f) } \\
\text { (mss/mss error) }\end{array}$ & $\begin{array}{l}\mathbf{F} \\
\text { ratio }\end{array}$ & $\begin{array}{l}\text { P value } \\
\text { significance }\end{array}$ \\
\hline Replicates & 2 & 6.925 & 3.4625 & 1.01042209 & 2.77 & $\mathrm{P}>0.05$ \\
\hline Treatments & 7 & 22666.4 & 3238.057 & 944.925482 & 2.77 & $\mathrm{P}<0.05$ \\
\hline No superdisintegrant & 1 & 145115.7 & 145115.7 & 42347.4685 & 4.6 & $\mathrm{P}<0.05$ \\
\hline starch malonate(A) & 1 & 9094.827 & 9094.827 & 2654.04019 & 4.6 & $\mathrm{P}<0.05$ \\
\hline croscarmellose sodium(B) & 1 & 5421.02 & 5421.02 & 1581.95477 & 4.6 & $\mathrm{P}<0.05$ \\
\hline $\begin{array}{l}\text { Starch malonate } \mathrm{X} \text { croscarmellose } \\
\text { sodium (AB) }\end{array}$ & 1 & 7482.189 & 7482.189 & 2183.44233 & 4.6 & $\mathrm{P}<0.05$ \\
\hline Crospovidone (C) & 1 & 491.596 & 491.596 & 143.456884 & 4.6 & $\mathrm{P}<0.05$ \\
\hline $\begin{array}{l}\text { Starch malonate X Crospovidone } \\
\text { (AC) }\end{array}$ & 1 & 82.88167 & 82.88167 & 24.1864175 & 4.6 & $\mathrm{P}<0.05$ \\
\hline $\begin{array}{l}\text { Croscarmellose X Crospovidone } \\
\text { (BC) }\end{array}$ & 1 & 20.64615 & 20.64615 & 6.02493174 & 4.6 & $\mathrm{P}<0.05$ \\
\hline $\begin{array}{l}\text { Starch malonate X Croscarmellose } \\
\text { sodium X Crospovidone (ABC) }\end{array}$ & 1 & 73.22027 & 73.22027 & 21.3670408 & 4.6 & $\mathrm{P}<0.05$ \\
\hline Error & 14 & 47.975 & 3.426786 & & & \\
\hline Total & 23 & 22721.3 & 987.8826 & & & \\
\hline
\end{tabular}

$\mathrm{P}<0.05$ indicate significance; $\mathrm{p}>0.05$ indicate non-significance, d. f-Degree of Freedom * S. S-Sum of Square * M. S. S-Mean Sum of Squares, All the values are expressed as mean $\pm S D$, where $n=3$, SD: Standard Deviation, ANOVA-Analysis of Variance 
Table 8: ANOVA of wetting time of aceclofenac fast dissolving tablets formulated employing starch malonate

\begin{tabular}{|c|c|c|c|c|c|c|}
\hline Source of variance & $\begin{array}{l}\text { Degree of } \\
\text { freedom }\end{array}$ & Sum square & $\begin{array}{l}\text { Mean sum square } \\
\text { (sum square/d. f) }\end{array}$ & $\begin{array}{l}\text { Variation } \\
\text { ratio(f)(mss/mss error) }\end{array}$ & F ratio & $\begin{array}{l}\text { Significant/non } \\
\text { significant }\end{array}$ \\
\hline Replicates & 2 & 45.75 & 22.875 & 202.2674162 & 2.77 & $\mathrm{P}<0.05$ \\
\hline Treatments & 7 & 9334.667 & 1333.523857 & 11791.40656 & 4.66 & $\mathrm{P}<0.05$ \\
\hline No superdisintegrant & 1 & 34656 & 34656 & 306438.4513 & 4.66 & $\mathrm{P}<0.05$ \\
\hline Starch malonate $(\mathrm{A})$ & 1 & 5828.167 & 5884.402 & 52031.5973 & 4.66 & $P<0.05$ \\
\hline Croscarmellose sodium (B) & 1 & 384 & 358.8267 & 3172.850249 & 4.66 & $P<0.05$ \\
\hline $\begin{array}{l}\text { Starch malonate } X \\
\text { Croscarmellose sodium (AB) }\end{array}$ & 1 & 1837.5 & 1901.04 & 16809.54967 & 4.66 & $\mathrm{P}<0.05$ \\
\hline Crospovidone (C) & 1 & 620.1667 & 640.6667 & 5664.961662 & 4.66 & $P<0.05$ \\
\hline $\begin{array}{l}\text { Starch malonate } \mathrm{X} \\
\text { crospovidone }(\mathrm{AC})\end{array}$ & 1 & 486 & 549.1267 & 4855.538306 & 4.66 & $\mathrm{P}<0.05$ \\
\hline $\begin{array}{l}\text { Croscarmellose sodium X } \\
\text { crospovidone (BC) }\end{array}$ & 1 & 48.16667 & 47.60167 & 420.9078381 & 4.66 & $\mathrm{P}<0.05$ \\
\hline $\begin{array}{l}\text { Starch malonate X } \\
\text { croscarmellose sodium X } \\
\text { crospovidone (ABC) }\end{array}$ & 1 & 130.6667 & 135.375 & 1197.025201 & 4.66 & $\mathrm{P}<0.05$ \\
\hline Error & 14 & 1.5833 & 0.113092857 & & & \\
\hline Total & 23 & 9382 & & & & \\
\hline
\end{tabular}

$\mathrm{P}<0.05$ indicate significance; $\mathrm{p}>0.05$ indicate non-significance, d. f-Degree of Freedom * S. S-Sum of Square * M. S. S-Mean Sum of Squares, All the values are expressed as mean $\pm \mathrm{SD}$, where $n=3$, SD: Standard Deviation, ANOVA-Analysis of Variance

Table 9: ANOVA of water absorption ratio of aceclofenac fast dissolving tablets formulated employing starch malonate

\begin{tabular}{|c|c|c|c|c|c|c|}
\hline Source of variance & $\begin{array}{l}\text { Degree of } \\
\text { freedom }\end{array}$ & Sum square & $\begin{array}{l}\text { Mean sum square } \\
\text { (sum square/d. f) }\end{array}$ & $\begin{array}{l}\text { Variation ratio(f) } \\
\text { (mss/mss error) }\end{array}$ & F ratio & $\begin{array}{l}\text { Significant/non- } \\
\text { significant }\end{array}$ \\
\hline Replicates & 2 & 0.225 & 0.1125 & 0.025204033 & 2.77 & $\mathrm{P}>0.05$ \\
\hline Treatments & 7 & 41564.93 & 5937.847143 & 1330.290606 & 4.66 & $\mathrm{P}<0.05$ \\
\hline No superdisintegrant & 1 & 369619.4 & 369619.4 & 82807.99488 & 4.66 & $\mathrm{P}<0.05$ \\
\hline Starch malonate $(\mathrm{A})$ & 1 & 8118.082 & 5884.402 & 1318.316979 & 4.66 & $\mathrm{P}<0.05$ \\
\hline Croscarmellose sodium (B) & 1 & 4256.007 & 358.8267 & 80.39004321 & 4.66 & $P<0.05$ \\
\hline $\begin{array}{l}\text { Starch malonate } \mathrm{x} \\
\text { Croscarmellose sodium (AB) }\end{array}$ & 1 & 3735.015 & 1901.04 & 425.9011042 & 4.66 & $\mathrm{P}<0.05$ \\
\hline Crospovidone $(\mathrm{C})$ & 1 & 0.081667 & 640.6667 & 143.532306 & 4.66 & $\mathrm{P}<0.05$ \\
\hline $\begin{array}{l}\text { Starch malonate } \mathrm{X} \\
\text { crospovidone }(\mathrm{AC})\end{array}$ & 1 & 164.3267 & 549.1267 & 123.0240647 & 4.66 & $\mathrm{P}<0.05$ \\
\hline $\begin{array}{l}\text { Croscarmellose sodium X } \\
\text { crospovidone (BC) }\end{array}$ & 1 & 9.881667 & 47.60167 & 10.6644804 & 4.66 & $\mathrm{P}<0.05$ \\
\hline $\begin{array}{l}\text { Starch malonate X } \\
\text { croscarmellose sodium X } \\
\text { crospovidone (ABC) }\end{array}$ & 1 & 126.96 & 135.375 & 30.32885262 & 4.66 & $P<0.05$ \\
\hline Error & 14 & 62.49 & 4.463571429 & - & - & - \\
\hline Total & 23 & 78046.62 & & - & - & - \\
\hline
\end{tabular}

$\mathrm{P}<0.05$ indicate significance; $\mathrm{p}>0.05$ indicate non-significance, d. f-Degree of Freedom * S. S-Sum of Square * M. S. S-Mean Sum of Squares, All the values are expressed as mean $\pm S D$, where $n=3$, SD: Standard Deviation, ANOVA-Analysis of Variance

Table 10: ANOVA of dissolution efficiency in 5 min of aceclofenac fast dissolving tablets formulated employing starch malonate

\begin{tabular}{|c|c|c|c|c|c|c|}
\hline Source of variance & $\begin{array}{l}\text { Degree of } \\
\text { freedom }\end{array}$ & Sum square & $\begin{array}{l}\text { Mean sum square } \\
\text { (sum square/d. f) }\end{array}$ & $\begin{array}{l}\text { Variation ratio(f) } \\
\text { (mss/mss error) }\end{array}$ & $F$ ratio & $\begin{array}{l}\text { Significant/non- } \\
\text { significant }\end{array}$ \\
\hline Replicates & 2 & 0.07 & 0.035 & 0.162090638 & 2.77 & $\mathrm{P}>0.05$ \\
\hline Treatments & 7 & 22644.45 & 3234.921429 & 14981.44228 & 4.66 & $\mathrm{P}<0.05$ \\
\hline No superdisintegrant & 1 & 120303.4 & 120303.4 & 557144.4261 & 4.66 & $\mathrm{P}<0.05$ \\
\hline Starch malonate $(\mathrm{A})$ & 1 & 10391.68 & 10391.68 & 48125.54416 & 4.66 & $\mathrm{P}<0.05$ \\
\hline Croscarmellose sodium (B) & 1 & 5005.482 & 5005.482 & 23181.19352 & 4.66 & $\mathrm{P}<0.05$ \\
\hline Starch malonate $\mathrm{X}$ & 1 & 6733.5 & 6733.5 & 31183.92326 & 4.66 & $\mathrm{P}<0.05$ \\
\hline \multicolumn{7}{|l|}{ Croscarmellose sodium (AB) } \\
\hline Crospovidone (C) & 1 & 328.56 & 328.56 & 1521.61429 & 4.66 & $\mathrm{P}<0.05$ \\
\hline $\begin{array}{l}\text { Starch malonate } \mathrm{X} \\
\text { crospovidone (AC) }\end{array}$ & 1 & 33.135 & 33.135 & 153.453523 & 4.66 & $\mathrm{P}<0.05$ \\
\hline $\begin{array}{l}\text { Croscarmellose sodium X } \\
\text { crospovidone (BC) }\end{array}$ & 1 & 0.081667 & 0.081667 & 0.378213033 & 4.66 & $\mathrm{P}<0.05$ \\
\hline $\begin{array}{l}\text { Starch malonate } \mathrm{X} \\
\text { croscarmellose sodium } \mathrm{X} \\
\text { crospovidone }(\mathrm{ABC})\end{array}$ & 1 & 152.0067 & 152.0067 & 703.9675157 & 4.66 & $\mathrm{P}<0.05$ \\
\hline Error & 14 & 3.023 & 0.215928571 & & & \\
\hline Total & 23 & 22647.54 & & & & \\
\hline
\end{tabular}

$\mathrm{P}<0.05$ indicate significance; $p>0.05$ indicate non-significance, d. f-Degree of Freedom * S. S-Sum of Square * M. S. S-Mean Sum of Squares, All the values are expressed as mean $\pm S D$, where $n=3$, SD: Standard Deviation, ANOVA-Analysis of Variance 


\section{Design expert study}

\section{Response Surface plot study (Factorial design expert study)}

To co-relate the independent variables (starch malonate (A), croscarmellose sodium (B) and crospovidone (C)) with dependent variables (disintegration time and dissolution efficiency in $5 \mathrm{~min}$ ), polynomial regression algorithm equation was developed. By using Design Expert 7.11 version software, contour plots and response surface plots were drawn. Optimized formula was selected based on the statistical analysis of equation developed and plots dawn,

Below are the equations 1 and 2 representing polynomial equation for disintegration time and dissolution efficiency in $5 \mathrm{~min}$ :

Disintegration time in $5 \mathrm{~min}=+388.37+276.63$ A-271.13B$149.88 \mathrm{C}+211.38 \mathrm{AB}+215.12 \mathrm{AC}+209.63 \mathrm{BC}-277.88 \mathrm{ABC}(\mathrm{R} 2=1.000)$

Dissolution efficiency in $5 \mathrm{~min}=+70.78+20.80 \mathrm{~A}+14.40 \mathrm{~B}+3.70 \mathrm{C}$ 16.78AB-1.17AC+0.075BC+2.50ABC $(\mathrm{R} 2=1.000)$

Table 11: Effect of starch malonate (A), croscarmellose sodium (B) and crospovidone (C) and their interaction on disintegration time and dissolution efficiency in 5 min are given in below

\begin{tabular}{lll}
\hline Parameters & Effect of disintegration time & Effect on dissolution efficiency in 5 min \\
\hline Starch Malonate (A) & + & + \\
Croscarmellose Sodium (B) & - & + \\
Crospovidone (C) & - & + \\
Starch Malonate (A)+Croscarmellose Sodium (B) & + & - \\
Starch Malonate (A)+Crospovidone (C) & + & + \\
Croscarmellose Sodium (B)+Crospovidone (C) & + & + \\
Starch Malonate (A)+Croscarmellose Sodium & - & \\
(B)+Crospovidone (C) & & \\
\hline
\end{tabular}

+means positive effect, (-) means negative effect, relation between response surface plots and contour plots of interaction between different superdisintegrants on disintegration time and dissolution efficiency in 5 min are given in below table 12 and table 13.

Table 12: Effect of different superdisintegrants on disintegration time (From response plots and contour plots-fig. 14 a, $14 b, 15$ a, $15 b, 16$ a, and 16b)

\begin{tabular}{lll}
\hline Superdisintegrants & Relation & Effect of disintegration time \\
\hline $\begin{array}{l}\text { Starch malonate (A)+Croscarmellose Sodium } \\
\text { (B) }\end{array}$ & Linear & $\begin{array}{l}\text { When the concentration of starch malonate and croscarmellose increases, } \\
\text { disintegration time of tablet decreases. Tablets will disintegrate more rapidly. }\end{array}$ \\
Starch malonate (A)+Crospovidone (C) & Linear & $\begin{array}{l}\text { When the concentration of starch malonate and crospovidone increases, } \\
\text { disintegration time of tablet decreases. Tablets will disintegrate more rapidly }\end{array}$ \\
Croscarmellose sodium (B)+Crospovidone (C) & Linear & $\begin{array}{l}\text { When the concentration of croscarmellose Sodium and crospovidone increases, } \\
\text { disintegration time of tablet decreases. Tablets will disintegrate more rapidly }\end{array}$ \\
\hline
\end{tabular}

Table 13: Effect of different superdisintegrants on dissolution efficiency in $5 \mathrm{~min}$ (From response plots and contour plots-fig. 17 a, $17 \mathrm{~b}, 18$ a, 18b, 19 a, and 19b)

\begin{tabular}{lll}
\hline Superdisintegrants & Relation & Effect of disintegration time \\
\hline Starch malonate (A)+Croscarmellose Sodium (B) & Linear & $\begin{array}{l}\text { Starch malonate in combination with croscarmellose sodium, enhance the } \\
\text { dissolution efficiency in 5 min. } \\
\text { Starch malonate (A)+Crospovidone (C) }\end{array}$ \\
$\begin{array}{lll}\text { Linear } \\
\text { Croscarmellose sodium (B)+Crospovidone (C) }\end{array}$ & $\begin{array}{l}\text { Linear } \\
\text { efficiency in 5 min. } \\
\text { Croscarmellose sodium in combination with crospovidone, enhance the } \\
\text { dissolution efficiency in 5 min. }\end{array}$ \\
\hline
\end{tabular}

No visible changes were observed in the fast-dissolving tablets after storage. Drug dissolution of best optimized formulation (F2) was evaluated before and after storage. No difference $(\mathrm{P}>0.05)$ was observed in the percent drug content before and after storage for 6 mo. The drug dissolution profiles of the fast-dissolving tablets before and after storage are given in table 14 and dissolution profile is shown in fig. 20. The drug dissolution characteristics of the

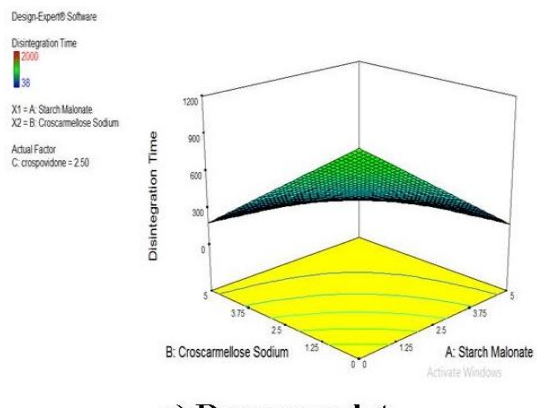

a) Response plot formulation tested remained unaltered during the storage period. The results, thus, indicated that the drug content and drug dissolution rate of the fast dissolving tablets formulated employing starch malonate were quite stable. Similarity factor (f2) and difference factor (f1) were calculated and found to be 56.7 and 4.52 respectively which is within the limits indicating the similarity before and after stability studies.
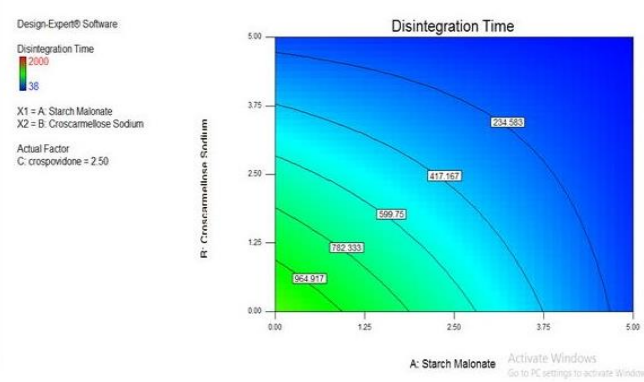

b) Contour plot

Fig. 15: a) Response surface plot and contour plot of aceclofenac fast dissolving tablets (Effect of starch malonate and croscarmellose sodium on disintegration time in five minutes) 
Table 14: Drug dissolution profile of optimized formulation F2 before and after storage for 6 mo for stability studies

\begin{tabular}{ll}
\hline Optimized formulation & Percent drug dissolution \\
\hline Formulation F2 (Before stability) & 97.88 \\
Formulation F2 (After stability) & 93.45 \\
\hline
\end{tabular}

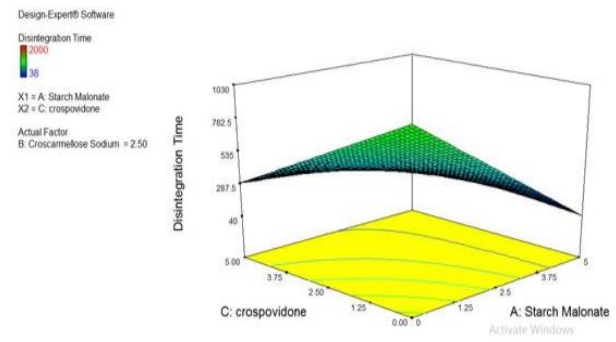

a) Response plot

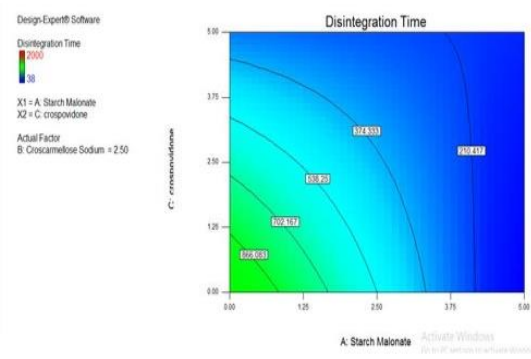

b ) Contour plot

Fig. 16: a) Response surface plot and contour plot of aceclofenac fast dissolving tablets (Effect of starch malonate and crospovidone on disintegration time in five minutes)

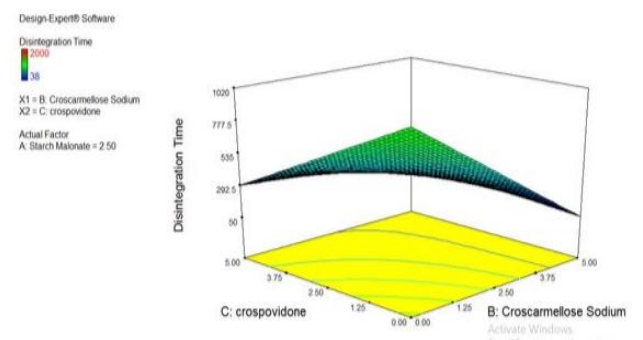

a) Response plot

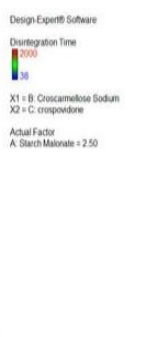

Fig. 17: a) Response surface plot and b) contour plot of aceclofenac fast dissolving tablets (Effect of croscarmellose sodium and

crospovidone on disintegration time in five minutes)

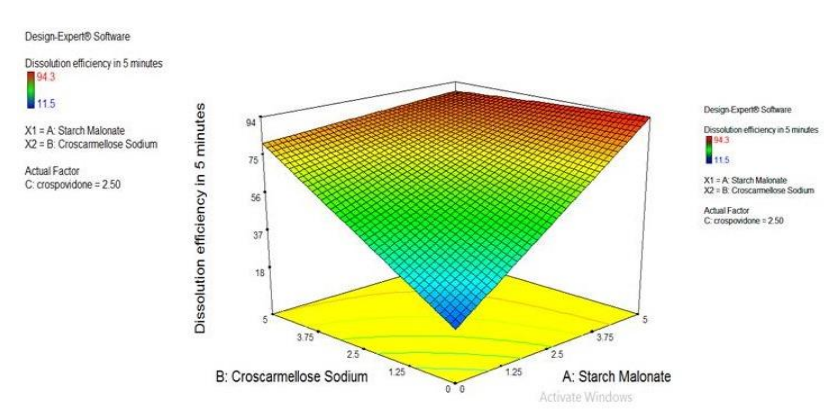

a) Response plot b ) Contour plot

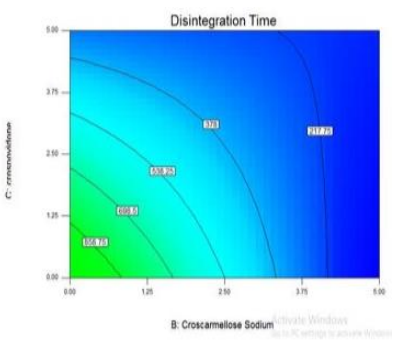

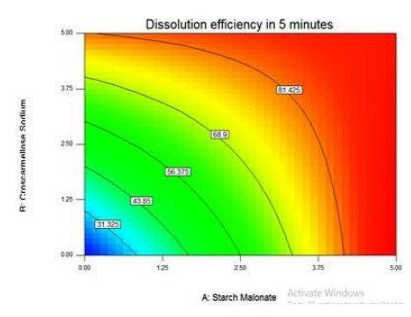

b ) Contour plot

Fig. 18: a) Response surface plot and b) contour plot of aceclofenac fast dissolving tablets (Effect of starch malonate and croscarmellose sodium on dissolution efficiency in $5 \mathrm{~min}$ )

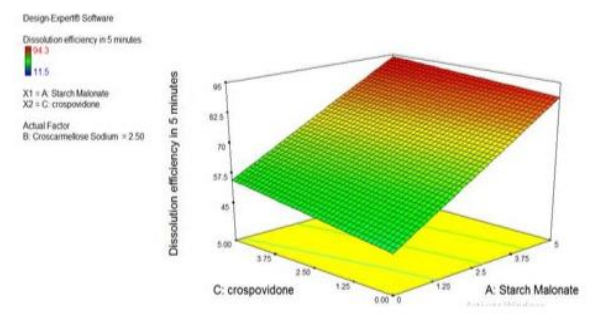

a) Response plot

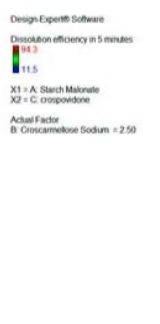

b) Contour plot

Fig. 19: a) Response surface plot and b) contour plot of aceclofenac fast dissolving tablets (Effect of starch malonate and crospovidone on dissolution efficiency in $5 \mathrm{~min}$ ) 


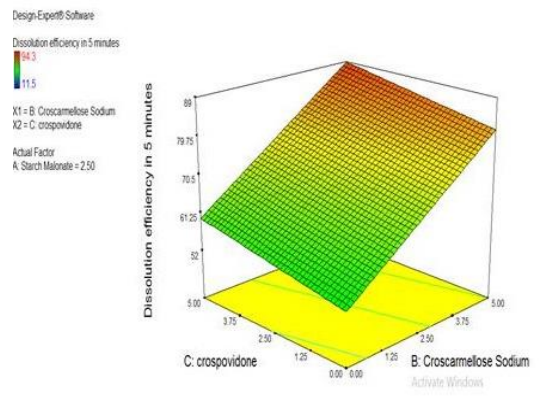

a) Response plot

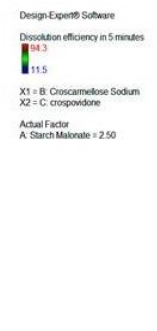

b ) Contour plot

Fig. 20: a) Response surface plot and b) contour plot of aceclofenac fast dissolving tablets (Effect of starch malonate and crospovidone on dissolution efficiency in 5 min)

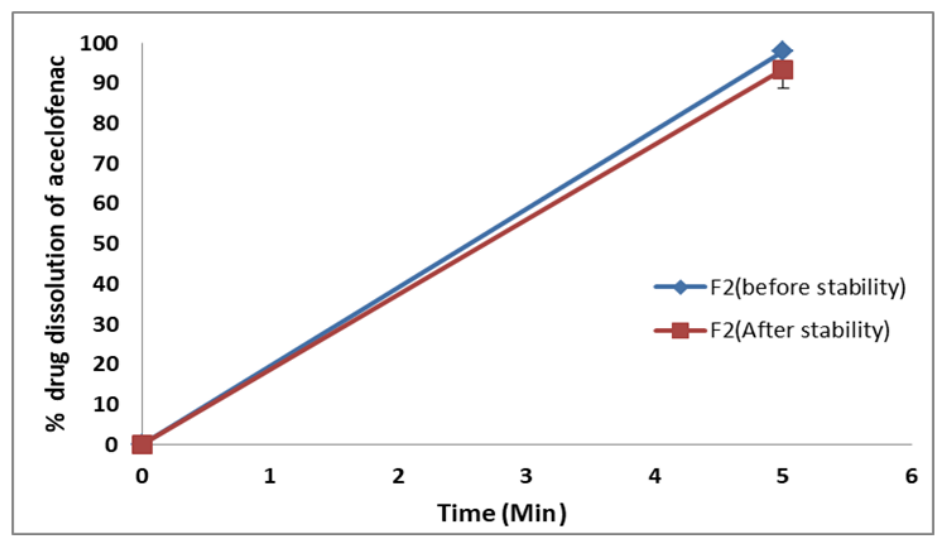

Fig. 21: Dissolution profiles of optimized formulation $F 2$ before and after storage for 6 mo

\section{CONCLUSION}

Starch malonate, a modified starch is an efficient superdisintegrant for fast dissolving tablets. The disintegration and dissolution efficiency of the fast dissolving tablets of Aceclofenac was excellent and depended on the concentration of superdisintegrant employed, i.e., starch malonate (5\%). The formulated fast dissolving tablets of aceclofenac employing starch malonate exhibited excellent dissolution efficiency in $5 \mathrm{~min}$, which can be used for the faster therapeutic action of aceclofenac. When compared to the marketed formulation, the optimized, fast dissolving tablet (formulation F2) of aceclofenac exhibited excellent dissolution efficiency in $5 \mathrm{~min}$. Overall, Starch malonate was found to be a superdisintegrant which enhanced the dissolution efficiency of poorly soluble drugs alone or in combination with known superdisintegrant crospovidone hence it could be used in the formulation of fast dissolving tablets to provide immediate drug dissolution of the contained drug within $5 \mathrm{~min}$.

\section{ABBREVIATION}

M-Molar, NaOH-Sodium Hydroxide, ${ }^{\circ} \mathrm{C}$-Degree Centigrade, \#Number, pH-Potential of hydrogen, ml-milliliter, S. I-Swelling Index, W/V-Weight/Volume, LBD-Loose bulk density, TBD-Tapped bulk density, FTIR-Fourier Transform Infrared Spectra, DSC-Differential Scanning Calorimetry, SEM-Scanning Electron Microscopy, TLC-Thin Layer Chromatography, HPLC-High Performance Liquid Chromatography, ICH-International Conference On Harmonization

\section{FUNDING}

Nil

\section{AUTHORS CONTRIBUTIONS}

All the authors have contributed equally.

\section{CONFLICT OF INTERESTS}

Declared none

\section{REFERENCES}

1. Ashish Masih, Amar Kumar, Shivam Singh, Ajay Kumar Tiwari. Fast dissolving tablets: a review. Int J Curr Pharm Res 2017;9:8-18.

2. Pratik Swarup Das, Sushma Verma, Puja Saha. Fast dissolving tablet using solid dispersion technique: a review. Int J Curr Pharm Res 2017;9:1-4.

3. T Gulsun, N Ozturk, MS Kaynak, I Vural, S Sahin. Preparation and evaluation of furosemide containing orally disintegrating tablets by direct compression. Pharmazie 2017;72:389-94.

4. Prateek Juneja, Birender Kaur, Oluwatoyin A Odeku, Inderbir Singh. Development of corn starch-neusilin UFL2 conjugate as tablet superdisintegrant: formulation and evaluation of fast disintegrating tablets. J Drug Delivery 2014. https://doi.org/10.1155/2014/827035

5. Inderbir Singh, Birender Kaur, Prateek Juneja Olim. Preparation and characterization of starch-metal silicate co-precipitates-evaluation as tablet superdisintegrant. Med 2014;44:157-66.

6. Inderbir Singh, Bhawna Sharma, Govind Arora. Application of SeDeM expert system in formulation and development of fast disintegrating tablets using starch-glycine conjugates as superdisintegrant. J Res Pharm 2019;23:839-50.

7. R Santosh Kumar, T Naga Satya Yagnesh, V Goutham Kumar. Optimisation of ibuprofen fast dissolving tablets employing starch Xanthate using $2^{3}$ factorial design. Int J Appl Pharm 2017;9:51-5.

8. Santosh Kumar R, Annu Kumari. Design, optimization, and evaluation of acyclovir fast dissolving tablets employing starch phthalate-a novel superdisintegrant. Asian J Pharm Clin Res 2019;12:132-42.

9. Santosh Kumar R, Sahithi Mudili. Formulation and evaluation of statistically designed ibuprofen fast-dissolving tablets employing starch glutamate as a novel superdisintegrant. Asian J Pharm Clin Res 2019;12:85-94.

10. Nadia H Naiem, Ebtessam A Essa, Gamal M Elmaghraby. Enhancing dissolution rate of indomethacin by in situ 
crystalization; development of orally disintegrating tablets. Int J Pharm Sci 2018;10:18-23.

11. Dattatraya M Shinkar, Pooja S Aher, Parag D Kothawade, Avish D Maru. Formulation and in vitro evaluation of fast dissolving tablet of verapamil hydrochloride. Int J Pharm Sci 2018;10:93-9.

12. Milind P Wagh, Chetan P Vewale, Santosh U Zate, Paresh I Kothawade, Ganesh H Mahale. Formulation and evaluation of fast dispersible tablets of aceclofenac using different superdisintegrant. Int J Pharm Pharm Sci 2010;2:154-7.

13. KPR Chowdary, S Gopinath, C Uma Maheswara Reddy, S Umamaheswari. Factorial studies on formulation development of aceclofenac tablets employing $\beta$ cyclodextrin and kolliphor HS15. World J Pharm Res 2015;3:1088-97.
14. Lovleen Kaur, Rajni Bala, Neha Kanojia, Manju Nagpal, Gitika Arora Dhingra. Formulation development and optimization of fast dissolving tablets of aceclofenac using natural superdisintegrant. ISRN Pharmaceutics 2014 DOI:10.1155/2014/242504

15. R Santosh Kumar, Sahithi Mudili. Optimization of statistically designed aceclofenac fast dissolving tablets employing starch glutamate as a novel superdisintegrant. Int J Appl Pharm 2020;12:77-88.

16. Jahan Nur Rahman Hazarika, Pulak Deb. Formulation evaluation and optimization of immediate release tablet of aceclofenac by direct compression method. Int J Curr Pharm Res 2017;9:118-22 